\title{
Risk disclosures, international orientation, and share price informativeness: Evidence from China
}

\author{
Youchao Tan \\ School of Accounting \\ Southwestern University of Finance and Economics \\ Chengdu, China \\ tanyouchao@swufe.edu.cn \\ Cheng (Colin) Zeng* \\ Alliance Manchester Business School \\ University of Manchester \\ Manchester, United Kingdom \\ cheng.zeng@mbs.ac.uk \\ Tamer Elshandidy \\ Bradford University School of Management \\ University of Bradford \\ Bradford, United Kingdom \\ T.Elshandidy@bradford.ac.uk
}

* Corresponding author. Tel: : +44 (0) 161 306-3438; Postal address: 1.11 Crawford House, Booth Street West, Manchester, M15 6PB. We are grateful for helpful comments from Qi Chen, Volkan Muslu, Christine Botosan, and participants at 2014 European Accounting Association Conference and 2014 British Accounting and Finance Association Conference. 


\title{
Risk disclosure, international orientation, and share price informativeness: Evidence from China
}

\begin{abstract}
This paper examines the effect of textual risk disclosure on the amount of firm-specific information incorporated into share prices, as measured by stock price synchronicity, for Chinese listed firms during 2007-2011. We find that synchronicity is inversely associated with risk disclosure, suggesting that risk disclosure is firm specific and useful to investors. In addition, our results document that the usefulness of risk information is statistically and economically more pronounced among internationally oriented firms than their domestically oriented peers, consistent with the necessity for risk disclosure to be more meaningful when it relates to greater uncertainty. Finally, we find that internationally oriented firms tend to disclose more risk factors than their domestically oriented counterparts. Our findings are robust to a variety of specifications and the use of alternative measures of risk disclosure, stock price synchronicity and international orientation. Our paper has practical implications since its findings shed light on the current debate on whether or not narrative sections of annual reports convey useful information to investors.
\end{abstract}

Keywords: Risk disclosure; stock price synchronicity; international orientation; China JEL Classification: D8; G24; G12; M4 


\section{Introduction}

Considerable attention has been paid recently to risk-related disclosure. Such attention is even greater during difficult times such as corporate scandals (e.g., Enron, WorldCom, American Insurance Group, and Lehman Brothers) and economic crises (e.g., 2007-2008's financial crisis). In such circumstances, the question of whether accounting is functioning effectively by providing the public with relevant information becomes increasingly crucial and, as a result, more pressure is put on professional bodies by the regulators (e.g., Barth and Landsman, 2010). For instance, in the US in 1997, the Securities and Exchange Commission (SEC) published Financial Reporting Release (FRR) No. 48 on the market risk of financial instruments, mandating the presentation of both qualitative and quantitative market risk information. ${ }^{1}$ Similarly, sections 302 and 404 of the Sarbanes-Oxley (SOX) Act (2002) obligate firms to provide information about their significant risks, derivatives, and hedging activities. Since the release of these two documents, the literature on risk disclosure has been dominated by empirical examinations of the extent to which US firms convey useful risk information based on the contents of FRR (48) (e.g., Rajgopal, 1999; Hodder and McAnally, 2001; Jorion, 2002; Linsmeier et al., 2002; Kravet and Muslu, 2013; Campbell et al., 2014).

Unlike the US mandatory approach towards risk disclosure, the China Securities Regulatory Commission (CSRC) encourages all Chinese listed companies to discuss risk factors in their annual reports, "following the principle of importance and disclosing major risks that may have an adverse impact on the realization of the firm's development strategies and business objectives in the next year" (CSRC [2005] No. 141). However, this framework only provides a guideline on risk reporting and the final decisions over the form and contents of their disclosure are left to the firms.

Arguably, two competing motives underpin managers' decisions to either withhold or reveal meaningful information (Beyer et al., 2010). Specifically, with regard to risk disclosure in the Chinese context, the voluntary nature of the CSRC's

\footnotetext{
${ }^{1}$ FRR (48) deals with the market risk of derivatives, and provides three formats for quantitative disclosure: sensitivity analysis, value at risk and tabular formats. These three formats should provide the impacts of any changes in the market rate and prices on cash flow, earnings and fair value.
} 
requirements allows management discretion over what risk information to disclose. Firms' managers might have disincentives to disclose risk as doing so might draw the market's attention to the firm's riskiness (e.g., Elshandidiy et al., 2013) or increase investors' perceptions of risk, causing them to increase their risk premium to compensate for the high risk exposure (e.g., Kravet and Muslu, 2013; Campbell et al., 2014). To avoid the potential deterioration in the market value of such firms, managers might therefore withhold risk information or minimize its usefulness. Furthermore, given the fact that the Chinese market has relatively low information transparency and poor investor protection (e.g., La Porta et al., 1998), investors have reasons to doubt the reliability and usefulness of the risk factors disclosed by Chinese listed firms.

On the contrary, investors need useful risk information as it provides direct information on a firm's risk profile, which may in turn affect investors' assessments of expected cash flows (Miihkinen, 2013). Providing risk information might reduce investors' uncertainty related to future cash flows, which reduces, as a result, their risk premiums (e.g., Jorgensen and Kirschenheiter, 2003; Elshandidy and Neri, 2015). Decreased risk premiums lead to a lower required rate of return, which is widely used in practice as a discount factor for investors' future cash flows. Thus, firm managers might have incentives to disclose more meaningful information to their investors.

To obtain a better understanding of the information content of China's corporate reporting, especially narrative reporting, the Association of Chartered Certified Accountants (ACCA) and the Shanghai Stock Exchange jointly conducted a survey in 2010. The results suggested that $82 \%$ of the respondents considered disclosed risk factors to be important in decision making (ACCA, 2011a). However, the empirical evidence on whether risk disclosure is informative in the context of China remains quite unclear, thus far, since there is little, if any, research investigating explicitly whether firms within the Chinese market provide proper risk disclosure, to an extent whereby investors can rely on it to better understand the firms' risks and uncertainties. Exploring whether risk disclosure is credible within one of the largest and fastest-growing economies in the world is becoming increasingly vital. This is 
especially true given the fact that the Chinese context is quite unique (e.g., the approach towards risk disclosure relies largely on encouraging rather than requiring firms to reveal risk information and investor protection is generally weak), differing from other contexts where the usefulness of risk disclosure has been tested recently (e.g., Kravet and Muslu, 2013; Campbell et al., 2014). Making generalizations, therefore, based on extant evidence on the usefulness of risk disclosure might go against a strong strand of literature that argues that accounting practices (measurements and disclosures) within a specific context (such as China) should reflect its underlying environmental factors (e.g., Nobes, 1998; Dober et al., 2011).

Using a unique dataset that measures the extent of the risk disclosure of Chinese listed firms during the period 2007-2011, this paper examines the effect of risk disclosure on the amount of firm-specific information incorporated into share prices, as measured by stock price synchronicity. Moreover, we investigate whether the association varies between firms with different levels of risks. Prior research demonstrates that firms possessing greater risks tend to disclose more risk (e.g., Dobler et al., 2011; Elshandidy el al., 2013; Campbell et al., 2014; Elshandidy et al., 2015). Stock market regulators around the world also encourage firms to disclose more meaningful risk factors to respond to market-wide fluctuations (Jorgensen and Kirschenheiter, 2003). Our paper pays special attention to the risk information disclosed by Chinese firms that are broadly classified as internationally oriented on the basis of their foreign sales, for the following reasons. First, internationalization is inherently risky due to increased exposure to various risk factors (e.g., currency and political risks), which in turn increases information asymmetry between management and information users such as analysts and investors (Duru and Reeb, 2002). Second, China did not become a member of the World Trade Organization (WTO) until December 2001. Through rapid development, China surpassed the U.S to become the world's largest trading nation in 2012 as measured by the sum of exports and imports of goods. ${ }^{2}$ Consequently, it is imperative for policy makers, firms and investors to

\footnotetext{
2 See the link: http://www.bloomberg.com/news/articles/2013-02-09/china-passes-u-s-to-become-the-world-s-biggesttrading-nation
} 
consider the risk-reporting practice in such an export-oriented economy.

Our results suggest that risk disclosure is inversely associated with stock price synchronicity, suggesting that such disclosure is not boilerplate but instead conveys useful information to investors. ${ }^{3}$ We find also that the negative association between risk disclosure and stock price synchronicity is more pronounced among internationally oriented firms (IOFs) than domestically oriented firms (DOFs), consistent with risk disclosure being more meaningful when it relates to greater uncertainty. These results explain why, as confirmed by additional analysis, IOFs, in the first place, have greater incentives to exhibit more risk factors in their narrative sections than do DOFs. Overall, our evidence is in line with the argument that firms' exposure to risk affects their choice of risk disclosure contents because investors demand more risk information from riskier firms (Lin et al., 2010). All of our findings are robust to a variety of sensitivity tests and alternative proxies for risk disclosure, stock price synchronicity and international orientation.

Our study contributes to the extant literature in several ways. First, risk disclosure has been studied regularly in the context of western economies such as the US (Kravet and Muslu, 2013; Campbell et al., 2014). However, it remains unclear whether risk disclosure is informative in emerging economies such as China, despite that country's increasingly important economic position in the world. To our best knowledge, our study is the first to provide direct evidence on the informativeness of risk disclosure in China. Our results help regulatory bodies and investors generally, and corporate disclosure users in particular, to better understand the extent to which, and in what manner, risk disclosure influences firm-specific information capitalization in an environment where overall country-level investor protection is relatively poor. Second, methodologically, our study differs from prior studies in that we measure informativeness using the amount of firm-specific information incorporated into stock prices, rather than regularly used measures such as stock return volatility, trading volume, bid-ask spread, and analyst forecast dispersion (Kravet and Muslu, 2013;

\footnotetext{
${ }^{3}$ Boilerplate is taken to mean that firms might engage in some forms of risk disclosure where they either will not be useful or less useful to investors. Firms might engage in such forms just to comply with regulations that might require filling some forms such as form 10-K.
} 
Miihkinen, 2013; Campbell et al., 2014). Gul et al. (2010) provide supportive evidence of the validity of stock price synchronicity as a measure of informativeness in the Chinese stock market. ${ }^{4}$ Lastly, our study contributes to the literature on international finance since there is little, if any, evidence on how international orientation affects the informativeness of the risk disclosure of Chinese firms. Our paper supports the idea that international diversification facilitates the flow of firm-specific risk information into the market.

The remainder of the paper is structured as follows. Section 2 provides institutional background and the literature review. Section 3 develops our research hypotheses. Section 4 explains the research design, including the measurement of the variables, model specification, sample selection and data sources. Section 5 reports the results of the main analyses, followed by the results of robustness checks and additional analysis in Section 6. Section 7 concludes the paper.

\section{Institutional background and literature review}

\subsection{Institutional background}

In the early 1990s, China opened two stock exchanges on the mainland, Shanghai and Shenzhen, to facilitate economic development by allowing firms to acquire external equity capital. Since its establishment, China's stock market has undergone substantial growth along with the country's economy. In terms of market capitalization, China's stock market had become the largest of any developing country by 2001 and is now the second largest in the world, behind the US. The Chinese stock market is characterized by a lack of transparency and an underdeveloped legal framework. More recently, numerous efforts have been launched by the CSRC to better regulate the stock market (Cheung et al., 2010). Glaeser et al. (2001) suggest that regulators can provide an effective substitute for ineffective judicial enforcement, particularly in emerging economies with relatively weak legal systems.

The primary objective of the corporate disclosure regulatory framework in China

\footnotetext{
4 They find a weaker return-earnings association for firms with high synchronicity, because that earnings are considered the most important value-relevant firm-specific information.
} 
is to improve the efficiency of the Chinese stock markets and protect investors' interests (CSRC, 1996). Since 1993, a growing number of disclosure rules and requirements have emerged in China. One of the landmark events was the issuance of Detailed Rules for the Implementation of Information Disclosure by Publicly Listed Firms in 1993. In 1994, the CSRC further released the Rules on the Contents and Formats of Listed Firms' Annual Reports, which was the first regulation aimed specifically at addressing such aspects for Chinese listed firms. A series of revisions have been made since then, substantially increasing the information that listed firms should disclose to the market.

Corporate risk reporting has received increasing regulatory attention in China since 2002, when listed firms were encouraged to disclose information about uncertainties in their operations for the first time. However, the requirements on risk disclosure did not become more detailed until 2005. Specifically, CSRC [2005] No. 141 requires sufficient disclosure of major risks by companies, including political, operational, financial and technology risks, as well as the measures that have been or will be taken to tackle the risks. In 2012, the CSRC further revised the Rules on the Contents and Formats of Listed Firms' Annual Reports (CSRC [2012] No. 22), classifying risk factors into more specific subcategories such as the risk of failure of sustainable growth in the future, that of the failure of sustainable technical innovation or product updating, the risk of product market competition, of reliance on large clients, of major investment failure, of key technician loss and so forth. These rules as a whole reflect the intent of the Chinese stock market regulators to strengthen the pertinence and effectiveness of the information disclosed by listed firms. ${ }^{5}$

\subsection{Literature review on risk disclosure}

Two main streams can be distinguished with regard to the current trend for risk disclosure. While the first stream concerns the question of why firms might provide risk information in the narrative sections of their annual reports, the second stream

\footnotetext{
${ }^{5}$ In the present paper, our scoring criteria are based on the 2005 regulatory framework because our sample covers the period of 2007-2011.
} 
complements the first by examining the extent to which the disclosed risk information is informative.

The first stream represents the principal trend of research in Europe generally (e.g., see Berretta and Bozzolan, 2004 regarding Italy; Miihkinen, 2012 regarding Finland) and the UK particularly (e.g., Marshall and Weetman, 2002, 2007; Linsley and Shrives, 2006; Abraham and Cox, 2007; Elshandidy et al., 2013; Abraham and Shrives, 2013). Those studies highlight factors that influence managers' decisions over the quantity (Marshall and Weetman 2002, 2007; Linsley and Shrives, 2006; Abraham and Cox, 2007; Elshandidy et al., 2013 and 2015) and/or the quality (Berretta and Bozzolan, 2004; Miihkinen, 2012; Abraham and Shrives, 2013) of risk disclosure. All previous research has conducted manual content analysis (with the exception of Elshandidy et al's (2013) automated method) to measure risk disclosure levels. Additionally, those studies' contexts were mainly restricted within a single country, with the exception of Dobler et al. (2011) who observed variations in the level of risk disclosure across Canada, Germany, the UK and the US.

The second stream is extensively representative of the principal trend in research on risk disclosure in the US. Early research in this stream (e.g., Rajgopal, 1999; Hodder and McAnally, 2001; Jorion, 2002; Linsmeier et al., 2002; Kravet and Muslu, 2013; Campbell et al., 2014) is motivated by FRR (48) regarding market risk. Rajgopal (1999) examines the usefulness of the SEC's requirements and finds a significant association between these requirements and both stock returns and share price sensitivity. He finds, however, incomparability of derivative market risk reporting between the three required formats. To overcome this weakness, Hodder and McAnally (2001) propose a methodology to convert information from the tabular format into the other two formats, suggesting that the tabular format is effective in providing useful information about firms' derivative market risk. Nevertheless, Linsmeier et al. (2002) and Jorion (2002) point out that value at risk measures are informative since this type of disclosure enables investors to predict variability in trading revenues and make adequate comparisons of trading portfolios. Instead of measuring the amount and/or quality of risk disclosure under FRR (48), previous 
studies indirectly measure the impact of risk disclosure by observing the impact of the new rules of FRR (48) on the market indicators around the filing dates of form 10-K.

Contrary to previous research, the most recent literature on textual disclosure (Kravet and Muslu, 2013; Campbell et al., 2014) applies a direct measure of risk disclosure so as to observe its impact on the market indicators (market liquidity and investor-perceived risk). For instance, Campbell et al. (2014) find that, while risk factor disclosure increases firms' riskiness, it decreases the information gap between insiders (management) and outsiders (shareholders). Consistent with these findings, Kravet and Muslu (2013) find that risk disclosure is likely to increase investors' risk perceptions. Their further investigation suggests that firm-level risk disclosure is more likely to be boilerplate.

\section{3 Literature review on stock price synchronicity}

A commonly used proxy for stock price synchronicity is the $\mathrm{R}^{2}$ statistic estimated from the market model. A high $\mathrm{R}^{2}$ indicates a high level of stock price synchronicity, that is, less firm-specific information incorporated into stock prices. In his seminal work, Ross (1988) argues that the extent to which stock prices move together depends on the relative amounts of firm-specific and market-specific information capture in stock prices (Morck et al., 2000). Using a sample of US firms, Ross finds that market-wide information explains only a small portion (e.g., $20 \%-35 \%$ ) of stock price movements. In addition, Morck et al. (2000) find that stock prices are less synchronous in economies in which private property rights are better protected. Their interpretation is that strong property rights protection encourages informed trading, which facilitates the inclusion of firm-specific information in stock prices, leading to lower synchronicity.

A related issue is whether firm-specific stock price movements are associated with the incorporation of private information or noise trading, which tends to decrease stock price synchronicity. Durnev et al. (2003) examine the relation between stock price synchronicity and various accounting measures of stock price informativeness, i.e., the ability of the share price to anticipate future earnings. They find that stock 
price synchronicity is negatively correlated with future earnings response coefficient and earnings incremental explanatory power, lending support to the argument that stock price synchronicity is related to the flow of firm-specific information. Based on these findings, several follow-up studies use stock price synchronicity as a measure of price informativeness and examine its association with analyst activity (Piotroski and Roulstone, 2004; Chan and Hameed, 2006), ownership structure (Boubaker et al., 2014), efficient capital allocation (Wurgler, 2000), corporate transparency (Jin and Myers, 2006), voluntary disclosure (Haggard et al., 2008), earnings management (Hutton et al., 2009), audit quality (Gul et al., 2010) and the International Financial Reporting Standards (Kim and Shi, 2012).

\section{Hypothesis development}

\subsection{Risk disclosure and share price informativeness}

Information asymmetry occurs when investors possess private information about a firm's value, which subsequently creates an adverse selection problem in the market as the informed investors may trade based on their private information (Brown and Hillegeist, 2007). To mitigate the information problem and facilitate the efficient allocation of resources in the capital market, previous studies have consistently emphasized the important role of firm disclosure in decreasing the information risk facing investors (e.g., Lev, 1988; Diamond and Verrecchia, 1991; Easley and O'Hara, 2004). Most of these studies focus on the economic consequences of accounting information and forward-looking disclosure. However, given the unique feature of risk disclosure in that it might be perceived as a bad signal by investors, prior literature has yielded mixed findings on its informativeness.

Risk disclosure could be informative and useful for investors for three main reasons. First, risk disclosure provides direct information on a firm's risk profile, which may in turn affect investors' assessments of expected cash flows as well as the discount rates they use in their valuation models (Miihkinen, 2013). Second, risk disclosure alleviates information asymmetry by lowering the risk of the adverse selection problem. Despite being intrinsically forward-looking, risk disclosure differs 
from other forward-looking information in that it guides users about the range rather than the level of a firm's future performance (Kravet and Muslu, 2013). In that sense, risk disclosure increases the amount of information available on a firm's risk and changes investors' risk perceptions (Kim and Verrecchia, 1994). Third, risk disclosure is typically related to unfavorable conditions and uncertainty about a firm's future performance (Kim and Yasuda, 2013). Since investors' distaste for risk information affects asset prices beyond the traditional risk factors (Barry and Brown, 1985; Caskey, 2009), learning about a firm's exposure to risk factors may mitigate the concerns of investors and enable them to reassess the firm's value. In addition, Kothari et al. (2009) suggest that the market places a heavier weight on bad news than good news, because management has an incentive to skew disclosure towards better news.

However, as suggested by prior literature, risk disclosure could also fail to be informative for investors for the following reasons. First, risk disclosure is mainly composed of qualitative descriptions of risk exposures (Schipper, 2007). Compared to quantitative information, qualitative might be more difficult to take into account in valuations as it fails to provide any direct figures (Miihkinen, 2013). Second, firms are likely to make boilerplate risk statements simply to conform to regulations. This is particularly the case in emerging countries with underdeveloped institutional frameworks, such as China. In addition, many firms may repeat their risk factors over consecutive annual reports, further reducing their informativeness (Kim and Yasuda, 2013). Finally, managers tend to withhold risky information because revealing it may reduce a firm's market value (Verrecchia, 2001). Alternatively, managers may be selective over risk disclosure by focusing on known risk factors that have already been perceived by investors and thus are less likely to affect investors' risk perceptions than unknown risk factors (e.g., Kravet and Muslu, 2013).

Our discussions above suggest that risk disclosure exerts two potentially offsetting influences on share price informativeness. As long as the opposing effects do not cancel each other out perfectly, then there should be an empirically observable risk disclosure effect. Thus, we hypothesize that: 
H1: Risk disclosure in the narrative sections of annual reports is likely to influence significantly the observed share price informativeness.

\subsection{International orientation and the informativeness of risk disclosures}

Prior literature suggests that foreign operations are inherently uncertain and risky (e.g., Madura, 1992; Bodnar and Weintrop, 1997; Knight and Kim, 2009). ${ }^{6}$ Reeb et al. (1998) find a significant positive relationship between the level of systematic risk and the degree of internationalization of a firm. In addition, they identify a set of risks associated with international business, including foreign exchange risk, political risk, the agency problem, asymmetric information, and managers' self-fulfilling beliefs. Their argument has been corroborated by a number of studies using archival data (e.g., He and Ng, 1998; Thomas, 2000; Duru and Reeb, 2002; Olibe et al., 2008). For example, Thomas (2000) suggests that foreign earnings are underpriced by the market, possibly due to the considerable uncertainty facing investors assessing firm value. Duru and Reeb (2002) find that analyst forecast accuracy and unbiasedness decline with corporate international diversification. Their interpretation is that internationalization yields greater complexity, which stems from the greater volatility of foreign earnings relative to that of domestic earnings. Additionally, managers have more discretion as a firm increases its operations abroad, leading to higher information asymmetry between analysts and management. In order to alleviate information asymmetry, investors may require more firm-specific risk information from firms that are perceived as risky. Thus, we predict the association between risk disclosure and price informativeness to be significantly greater among IOFs than their domestically oriented peers. We test the following hypothesis:

H2: The impact of risk disclosure on share price informativeness is more pronounced among internationally oriented firms.

\footnotetext{
${ }^{6}$ We also note that some of the international finance literature posits the idea that international business decreases systematic risks owing to diversification benefits (Shapiro, 1978; Michel and Shaked, 1986). However, a growing number of recent studies have provided evidence inconsistent with this argument.
} 


\section{Research design}

\subsection{Measurement of key variables}

\subsubsection{Share price informativeness}

Our measure of price informativeness is stock price synchronicity. Theoretically speaking, the stock price of a firm conveys less firm-specific information if its stock return is strongly correlated with the market return. Following prior literature (e.g., Morck et al., 2000; Piotroski and Roulstone, 2004; Gul et al., 2010), we first estimate the market model by regressing individual returns on market and industry returns:

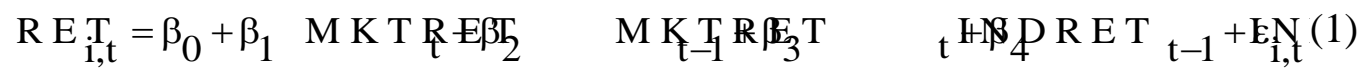

where, for firm $i$ and time $t, R E T$ denotes the firm-specific return on A-shares traded on the Shanghai and Shenzhen stock exchanges, and MKTRET and INDRET denote the value-weighted A-share market and industry returns, respectively. To control for autocorrelations possibly caused by thin trading, the lagged market and industry returns are also included in the model.

In Eq. (1) we only take the systematic return of the Chinese stock markets into consideration. However, Chinese stock returns may also be influenced by market factors outside of China (Gul et al., 2010). Specifically, prior studies (e.g., Ding and Cheng, 2011; Ding et al., 2013) suggest that the US market leads the movements in the Chinese market. To address this issue, we also estimate a two-factor market model incorporating the returns of both the Chinese and US markets:

$$
\operatorname{RET}_{\mathrm{i}, \mathrm{t}}=\beta_{0}+\beta_{1} \text { MKTRET }_{\mathrm{t}}+\beta_{2} \mathrm{USRET}_{\mathrm{t}}+\varepsilon_{\mathrm{i}, \mathrm{t}}
$$

where USRET is the weighted-average return on all US stocks, and the other variables are defined as earlier. Eqs (1) and (2) are estimated based on daily returns over the 30 trading days following the risk disclosure release dates. Given the length of annual reports, it is reasonable to assume that investors may not be able to update their assessments of firm value promptly (Kravet and Muslu, 2013). Thus, we use a medium-length testing period to allow time for the investors and financial analysts to interpret the risk disclosure information and react based on their interpretations. As in prior studies, stock price synchronicity is defined as the ratio of firm-specific return 
variation to total return variation, which is essentially equal to $1-R_{i, t}^{2}$ in the market models we estimate. Since $R^{2}$ is bounded within $[0,1]$, we use a logarithmic transformation of $R^{2}$ as follows:

$$
\mathrm{SYNCH}_{\mathrm{i}, \mathrm{t}}=\log \left(\frac{\mathrm{R}_{\mathrm{i}, \mathrm{t}}^{2}}{1-\mathrm{R}_{\mathrm{i}, \mathrm{t}}^{2}}\right)
$$

where $R_{i, t}^{2}$ is the goodness-of-fit measure from the estimation of one or other of our market models for firm $i$ and year $t$. As $S Y N C H$ is a monotonically increasing function of $R^{2}$, a higher value of $S Y N C H$ will indicate a higher correlation between the firm and the market, suggesting that the stock price contains less firm-specific information. In our empirical analyses, we obtain two alternative measures of $S Y N C H$ : one

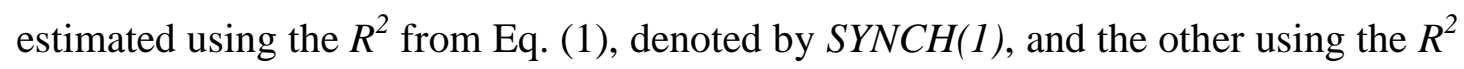
from Eq. (2), denoted by $\operatorname{SYNCH(2).~}$

\subsubsection{Extent of risk disclosure}

Risk disclosure data are taken from the database of the Research Centre of Corporate Governance at Nankai University, which has been compiling a Corporate Governance Index (including a section on disclosure scores) for all A-share listed firms in China on a yearly basis since 2004. As in other studies, our risk disclosure data are restricted to those included in the annual report, based on the view that the annual report is the most influential disclosure document in terms of the organization communicating a view of its operations to the public (Neimark, 1992), and because the annual report is produced regularly (Gray et al., 1995).

Under the regulatory requirements of the $\mathrm{CSRC}^{7}$ the following risk categories are suggested as typical of Chinese listed firms: operational risks, financial risks, investment risks, and new products/R\&D risks. A total of 18 criteria (topics and subtopics) form the scorecard used to assess each firm in our sample. These rules are broadly consistent with IFRS-converged China Accounting Standards (CAS). The

\footnotetext{
7 The regulations include the following: the Securities Law of the People's Republic of China, the Company Law of the People's Republic of China, the Circular by the CSRC on the Content and Format Standards of Information Disclosure for Securities-Issuing Companies No. 2 - Content and Format of Annual Report, and the Guidelines for the Corporate Governance of Listed Companies.
} 
extent of risk disclosure is measured in two different ways. In our main analysis, firms that disclose a specific scoring criterion receive a score of one, and other firms receive zero. The total score for risk disclosure is computed as the equally weighted sum across all 18 criteria $\left(R \_D I S C\right)$. Firms that disclose more risk information have higher scores. As a robustness check, we also use the number of sentences in the section on risk factors (NUM_RDISC) to measure the extent of risk disclosure. The list of criteria is provided in Appendix 1.

\subsubsection{International orientation}

In prior studies, especially those in the international economics literature, the most common proxy for international orientation is the foreign sales ratio (e.g., foreign sales divided by total sales) (Sullivan, 1994; O’Connor et al., 2009). Specifically, an IOF is defined by a dummy variable (denoted INTER), which equals one if foreign sales are equal to or exceed $25 \%$ of total sales. In order to enhance the robustness of our analyses, an alternative measure of international orientation is defined. It is also a dummy variable (denoted INTER_D), which is coded as one if foreign sales are more than zero. We use INTER in the main analysis because it is well established in the international business literature that $25 \%$ of foreign sales is a benchmark for determining whether a firm has an international orientation $\left(\mathrm{O}^{\prime} \mathrm{Connor}\right.$ et al., 2009; Koster and Karlsson, 2009).

\subsection{Model specification}

To mitigate endogeneity concerns, we adopt a lead-lag approach by regressing the informativeness measure for firm $i$ in year $t+1^{8}$ on the extent of risk disclosure and control variables in year $t$. In order to test $\mathrm{H} 1$, that risk disclosure is associated with price informativeness, we estimate the following regression equation:

$$
\begin{aligned}
\text { SYNCH }_{i, t+1} & =\alpha+\beta_{1} \mathrm{R}_{-} \text {DISC }_{i, \mathrm{t}}+\beta_{2} \mathrm{SIZE}_{\mathrm{i}, \mathrm{t}}+\beta_{3} \mathrm{LEV}_{\mathrm{i}, \mathrm{t}}+\beta_{4} \mathrm{VOL}_{\mathrm{i}, \mathrm{t}}+\beta_{5} \mathrm{STDROA}_{\mathrm{i}, \mathrm{t}} \\
& +\beta_{6} \mathrm{~B} / \mathrm{M}_{\mathrm{i}, \mathrm{t}}+\beta_{7} \mathrm{OWNCON}_{\mathrm{i}, \mathrm{t}}+\beta_{8} \mathrm{BIG}_{\mathrm{i}, \mathrm{t}}+\beta_{9} \text { DUALITY }_{\mathrm{i}, \mathrm{t}}+\beta_{10} \mathrm{BSIZE}_{\mathrm{i}, \mathrm{t}}
\end{aligned}
$$

\footnotetext{
${ }^{8}$ As discussed in section 4.1.1, stock price synchronicity is computed using daily returns over the 30 trading days following the release of the risk disclosure.
} 


$$
+\beta_{11} \text { DIND }_{i, t}+\text { Year+Industry+ } \varepsilon_{i, t}
$$

where $S Y N C H$ is the stock price synchronicity as defined in section 4.1.1. The main explanatory variable is $R \_D I S C$, which was defined in section 4.1.2. If the null hypothesis $\mathrm{H} 1$ is true, then $\beta_{1}$ should be significantly different from zero. To test $\mathrm{H} 2$, we estimate Eq. (4) for IOFs and DOFs, respectively. If $\mathrm{H} 2$ is true, then we should observe a more significant $\beta_{1}$ for the former group.

Following previous research (Piotroski and Roulstone, 2004; Chan and Hameed, 2006; Gul et al., 2010), we control for a number of factors that may also affect price informativeness. Firm size (SIZE) is measured as the natural log of total assets in the year, leverage ratio $(L E V)$ is measured as the ratio of total liabilities to total assets, trading volume turnover $(V O L)$ is computed as the total number of shares traded in the year, divided by the total number of outstanding shares in that year, earnings volatility (STDROA) is computed as the standard deviation of a firm's return on assets (ROA) over the preceding five years, book-to-market ratio $(B / M)$ is measured as the book value divided by the market value of equity in the year, ownership concentration $(O W N C O N)$ is defined as the Herfindahl index of the top ten shareholders of the firm, $B I G 4$ is a dummy variable that equals one if the firm is audited by one of the Big 4 auditors (i.e., PricewaterhouseCoopers, Deloitte, Ernst \& Young and KPMG) and otherwise equals zero, DUALITY is also a dummy variable, that equals one if the CEO also serves as board chairman, and otherwise equals zero, board size (BSIZE) is measured as the log of the number of board members, and the percentage of independent directors (DIND) is computed as the number of independent directors divided by the total number of board members. Additionally, we include year and industry dummies to control for industry and year fixed effects. All continuous variables are winsorized at the $1^{\text {st }}$ and $99^{\text {th }}$ percentiles to mitigate the effect of outliers. The variable definitions are presented in Appendix 2.

\subsection{Sample and data sources}

Our sample covers the five-year period, 2007-2011. We start from 2007 because it was the first year of China's adoption of IFRS. We restrict our sample to the 
post-IFRS period to mitigate possible confounding effects caused by the change in standards. To construct the price informativeness measure, the Chinese market returns are extracted from the China Stock Market and Accounting Research (CSMAR) database and the US stock returns from the Centre for Research in Security Prices (CRSP) database. Our risk disclosure data are obtained from the database of the Research Centre of Corporate Governance at Nankai University. The accounting and financial data used in our analyses are downloaded from the CSMAR database.

The initial sample includes 7,035 observations. We exclude 430 dual-listed firm-year observations $(A+B)^{9}$ because the value of the informativeness measure for such firms differs significantly from that for A-share firms (Gul et al., 2010). In addition, we delete 428 specially treated (ST) firm-year observations, since such firms are subject to many trading restrictions. ${ }^{10}$ We exclude another 160 financial industry observations, and 584 observations with insufficient accounting or financial data. The sample selection process yields a final sample of 5,433 observations.

Panel A of Table 1 presents the distribution of our sample across industries based on CSRC industry classifications. Over $55 \%$ of the sample comes from the Manufacturing industry, followed by Trade (6.92\%) and Real Estate (6.48\%). Firms in the Media industry account for less than $1 \%$ of the sample. Panel B presents the yearly distribution of our sample. The number of firms increases monotonically over the five-year period, reflecting the fact that Chinese stock markets are growing steadily.

\section{[Insert Table 1]}

\section{Empirical analysis}

\footnotetext{
${ }^{9}$ In China, firms can issue A-shares, which are traded in the Chinese currency (RMB) and are mainly intended for domestic investors, and/or B-shares, which are traded in US dollars in Shanghai, or Hong Kong dollars in Shenzhen, and are mainly intended for foreign investors. Prior to $19^{\text {th }}$ February 2001, B-shares could only be purchased by foreign investors. Since then, individual domestic investors have also been permitted to purchase B-shares with foreign currency.

${ }^{10}$ The CSRC mandates that if a listed firm reports losses in two consecutive years, its stock will be specially treated (ST). ST status imposes huge costs on listed firms. For instance, the daily stock price movement is restricted within a range of 5\%. An ST firm's semi-annual report must be audited, which is not required for other firms. More seriously, ST firms are not allowed to raise additional capital from the stock market. If an ST firm reports one further year of losses, it will be suspended from trading on the stock exchanges, and the stock will be delisted if a fourth annual loss is reported.
} 


\subsection{Summary statistics}

Table 2 presents summary statistics on the key variables used in the full sample analysis (Panel A) and subsample analysis (Panel B). In Panel A, the mean and median of SYNCH(1) are -0.489 and -0.387 , respectively, while the mean and median of $\operatorname{SYNCH(2)}$ are 0.039 and 0.076 , respectively. Our measure of $\operatorname{SYNCH(1)}$ is computed using the same specification of the market model but a different sample period and different return data to that used in Gul et al. (2010). ${ }^{11}$ They report a mean and median of -0.232 and -0.151 , which are higher than our corresponding figures. This suggests that, given the rapid development of the Chinese capital market, the informational efficiency of the stock prices of Chinese listed firms has improved substantially over time. Both $\operatorname{SYNCH(1)}$ and $\operatorname{SYNCH(2)}$ display considerable cross-sectional variations, as reflected in the high discrepancy between the minimum and maximum values. For example, $S Y N C H(1)$ has a minimum value of -4.430 and a maximum value of 1.678 , with a standard deviation of 1.11 . This significantly high variation in price synchronicity suggests that the firm-specific information flow to the market varies widely across firms within China. In addition, the mean and median values of $R \_D I S C$ are 0.519 and 0.500 , respectively, suggesting that the risk disclosure scores are evenly distributed across firms.

Panel B presents the summary statistics for IOFs and DOFs, respectively. The price informativeness tends to be significantly higher among the IOFs based on both measures of stock price synchronicity. For example, the means of $\operatorname{SYNCH(1)}$ are -0.596 and -0.470 for the IOF and DOF subsamples, respectively. The difference between the two groups is significant at the $1 \%$ level. Both $R \_D I S C$ and NUM_RDISC are significantly higher for the IOFs than the DOFs. For instance, the mean of $R_{-} D I S C$ is 0.541 for the former, while it is 0.515 for the latter. The difference in the mean of $R \_D I S C$ is significant at the 5\% level between the two subsamples. This indicates that firms with more international business tend to disclose more risk factors to compensate for the uncertainty facing investors.

\footnotetext{
11 Specifically, their sample period is 1996-2003. Additionally, unlike in our study where we use daily returns over the 30 trading days following the risk disclosure release dates, they use daily returns over the whole fiscal year to compute stock price synchronicity.
} 


\section{[Insert Table 2]}

\subsection{Correlation matrix}

Table 3 presents the Pearson correlations for the variables used in the main analysis. $R \_D I S C$ significantly negatively correlates with both measures of synchronicity (coefficients: -0.060 for $S Y N C H(1)$ and -0.037 for $S Y N C H(2)$ ). This lends initial support to the argument that risk disclosure is positively associated with price informativeness. Consistent with Gul et al. (2010), stock price synchronicity is positively correlated with firm size (SIZE), book-to-market ratio $(B / M)$, and ownership concentration $(O W N C E N)$, but negatively correlated with earnings volatility (STDROA). However, correlation coefficients cannot be used directly to establish causality due to the fact that correlations merely measure the covariation with which two variables move together (Chen and Metcalf, 1980). In addition, as $R \_D I S C$ is a quantitative measure of a qualitative construct, it is difficult to interpret the economic significance of the correlations between $R \_D I S C$ and the other variables (Kravet and Muslu, 2013). Finally, since the correlations among the non-dependent variables are less than 0.7 , multicollinearity should not be a concern in this study. ${ }^{12}$

\section{[Insert Table 3]}

\subsection{Effect of risk disclosure on stock price informativeness}

Table 4 presents the results of Eq. (4) testing the effect of the extent of risk disclosure on stock price synchronicity. As seen in columns (1a) and (1b), where SYNCH(1) is the dependent variable, the coefficient on $R \_D I S C$ is significantly negative $(-0.156, \mathrm{t}$-stat $=-3.590)$. This indicates that synchronicity is inversely associated with the extent of risk disclosure, which supports the notion that risk disclosure is informative and useful to investors. Thus, the amount of firm-specific information captured in stock prices tends to be higher when more risk factors are disclosed.

\footnotetext{
${ }^{12}$ Lind et al. (2002) point out that multicollinearity may exist if the correlation coefficients exceed 0.7, and this is a typical threshold used to identify the presence of multicollinearity.
} 
Turning to the control variables, the signs of their coefficients are broadly consistent with prior studies. For instance, the coefficient on SIZE is positive and significant in column (2a) $(0.111, \mathrm{t}$-stat=5.470), suggesting that the stock prices of large firms tend to mirror the market to a greater extent than those of small firms, which is partly because large firms account for a major proportion of the market index (Chan and Hameed, 2006; Gul et al., 2010). The coefficient on $B / M$ is significantly positive $(0.786$, t-stat=8.820), indicating that firms with fewer growth opportunities tend to have less firm-specific information incorporated in their stock prices (Gul et al., 2010). The $L E V$ coefficient is significantly negative $(-0.545$, $\mathrm{t}-\mathrm{stat}=-6.190)$. This suggests that firms with greater financial risks tend to disclose more firm-specific information to satisfy the information demand of investors. The coefficient on STDROA is negative and significant $(-1.085$, t-stat=-3.530), suggesting that volatile earnings increase the firm-specific information incorporated in stock prices. The coefficients on BSIZE and DIND are negative, suggesting that superior corporate governance tends to enhance stock price informativeness, possibly by improving information transparency (Ding et al., 2013). In contrast to Gul et al. (2010), who find a significantly negative coefficient on $V O L$, our $V O L$ coefficient is significantly positive $(0.267, \mathrm{t}-\mathrm{stat}=9.350)$. This suggests that active trading enhances the incorporation of market-related information in stock prices. The above findings are not sensitive to the alternative measure of stock price synchronicity $\operatorname{SYNCH(2).}$

[Insert Table 4]

\subsection{Effect of international orientation on informativeness of risk disclosure}

Table 5 presents the regression results from testing hypothesis $\mathrm{H} 2$, that the effect of risk disclosure on stock price synchronicity is more pronounced among IOFs. A firm is defined as internationally oriented if its foreign sales account for at least $25 \%$ of total sales (in Panel A) or if its foreign sales are greater than zero (in Panel B). To enhance the robustness of our analyses, the results are reported using two alternative measures for stock price synchronicity (SYNCH(1) and $S Y N C H(2))$ in each panel. As seen in column (1), for example, the coefficients on $R \_D I S C$ are $-0.429(\mathrm{t}-\mathrm{stat}=-3.79)$ 
for IOFs and -0.095 (t-stat=-2.00) for DOFs. The difference in $R \_D I S C$ is significant at the $1 \%$ level. This suggests that international orientation facilitates the capturing of firm-specific information in stock prices and thus reduces stock price synchronicity, which is in line with our hypothesis H2. The findings are robust to the different measures used for international orientation and price synchronicity, as shown in columns (2)-(4).

The signs of the coefficients on the control variables are consistent with those reported in Table 4. In addition, these coefficients do not vary significantly between the two subsamples, with $O W N C E N$ being the only exception. The coefficients on OWNCEN are positive and significant at the $10 \%$ level for IOFs $(0.555$, t-stat $=1.93)$, while being negative but insignificant for DOFs $(-0.093$, t-stat=-0.920). This suggests that IOFs with a concentrated ownership structure are less likely to disclose private information to outside shareholders.

[Insert Table 5]

\section{Robustness check and additional analysis}

\subsection{Alternative measure of risk disclosure}

Although our main proxy for risk disclosure is constructed following a rigorous process, some doubt can still be cast on the reliability of this measure. To provide robust evidence, we redo the above tests replacing $R \_D I S C$ with $N U M \_R D I S C$, which is computed as Log $(1+$ Number of sentences in the section on risk factors in the annual report). Table 6 presents the results of the regression where the dependent

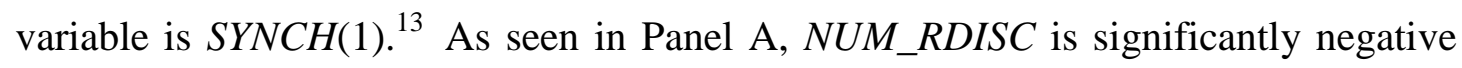
related to synchronicity for the full sample (-0.030, t-stat=-2.35). A comparison of the coefficient on NUM_RDISC in Panel B shows that the stock prices are less synchronous for IOFs $(-0.148, \mathrm{t}-\mathrm{stat}=-4.19)$ than for DOFs $(-0.010$, $\mathrm{t}-\mathrm{stat}=-0.70)$. The difference between the two subsamples is significant at the $1 \%$ level. Put together, these findings are consistent with the results reported in the main analyses, lending more confidence to the validity of our risk disclosure measures.

\footnotetext{
13 The results (untabulated) remain qualitatively similar if $S Y N C H(2)$ is used as the dependent variable.
} 


\section{[Insert Table 6]}

\subsection{Industry-adjusted risk disclosure}

One may argue that there is a lack of firm-specific information in our risk disclosure measures (Johnson, 2010). To capture the firm-specific risk information, we follow Kravet and Muslu (2013) by dividing risk disclosure into industry-level risk disclosure, defined as the industry median of risk disclosure, and firm-specific risk disclosure, defined as risk disclosure net of industry-level risk disclosure (Adj. $\left.R_{-} D I S C\right)$. We reexamine the main tests using $A d j . \quad R \_D I S C$ as the independent variable. As seen in Panel A of Table 7, the coefficient on Adj. $R \_D I S C$ is negative and significant at the $1 \%$ level, consistent with the findings reported in Table 4. Panel B presents the results of the subsample analysis. The coefficient on Adj. R_DISC is substantially lower among IOFs $(-0.421$, t-stat=-3.720) than DOFs $(-0.102$, $\mathrm{t}$-stat=-2.180). The difference is significant at the $1 \%$ level $(\mathrm{t}-\mathrm{stat}=-2.75)$. Taken together, the results collectively suggest that firm-specific risk disclosure is informative for investors, and more so for firms that are perceived to be riskier.

[Insert Table 7]

\subsection{Alternative measure of informativeness: stock price crash risk}

In this subsection, we use an alternative measure to proxy for the amount of firm-specific information, that is, stock price crash risk. Prior literature consistently suggests that managers have a self-serving bias to disclose favorable information but withhold unfavorable news about the firm (e.g., Kothari et al., 2009). Since risk disclosure is designed to convey unfavorable information and uncertainties of the firm, managers tend to avoid providing meaningful risk factor disclosure or even concealing negative news in order to protect their own wealth and jobs (Campbell et al., 2014). Once the unfavorable information becomes publically available, stock prices will inevitably drops, increasing the stock price crash risk. Thus, we expect that the presence of risk disclosure reduces future stock price crash risk, and especially so for the internationally oriented firms. 
Following prior literature (e.g., Kim et al., 2011a, b; Xu et al., 2014), we use two measures of crash risk for robustness. We first estimate firm-specific weekly returns $\left(W_{j, \tau}\right)$, measured as natural $\log$ of one plus residual returns from the following equation:

$r_{j, \tau}=\alpha_{j}+\beta_{1, j} r_{m, \tau-2}+\beta_{2, j} r_{m, \tau-1}+\beta_{3, j} r_{m, \tau}+\beta_{4, j} r_{m, \tau+1}+\beta_{5, j} r_{i, \tau+1}+\varepsilon_{j, \tau}$

where $r_{j, \tau}$ is the return on stock $j$ in week $\tau, r_{m, \tau}$ is the value-weighted A share market return.

Our first crash risk measure is the negative conditional skewness of firm-specific weekly returns (NCSKEW). We calculate NCSKEW for firm $j$ over fiscal year $t$ by taking the negative of the third moment of firm-specific weekly returns for each year and dividing it by the standard deviation of firm-specific weekly returns raised to the third power. The formula for the negative conditional skewness is as follows:

$$
\operatorname{NCSKEW}_{j, t}=-\left[n(n-1)^{3 / 2} \sum W_{j, \tau}^{3}\right] /\left[(n-1)(n-2)\left(\sum W_{j, \tau}^{2}\right)^{3 / 2}\right]
$$

The second measure for crash risk is down-to-up volatility (DUVOL), which is calculated as follows:

DUVOL $_{\mathrm{j}, \mathrm{t}}=\log \left\{\left(\mathrm{n}_{\mathrm{u}}-1\right) \sum_{\text {Down }} \mathrm{W}_{\mathrm{j}, \tau}^{2} /\left(\mathrm{n}_{\mathrm{d}}-1\right) \sum_{\mathrm{Up}} \mathrm{W}_{\mathrm{j}, \tau}^{2}\right\}$

A stock with high NCSKEW or DUVOL represents a highly left-skewed return distribution and a high probability of price crash. Consistent with prior literature, we control for the following variables: stock turnover (DTURN), firm size (SIZE), market-to-book ratio $(M B)$, leverage ( $L E V)$, stock return volatility (SIGMA), return on assets $(R O A)$, the average firm-specific weekly returns in a year (WRET), and industry and year dummy variables. All the control variables are lagged one year.

Columns 1 and 4 of Table 8 report the results for the full sample. The coefficients on $R \_D I S C$ are negative in both columns, despite insignificance in Column (1) $(\mathrm{t}-\mathrm{stat}=-1.512)$. The results suggest that risk disclosure reduces future crash risk, consistent with our hypothesis H1. When splitting the sample into IOFs and DOFs, we find that the negative relation between risk disclosure and stock price crash risk is confined to the IOF sample, consistent with the hypothesis $\mathrm{H} 2$ that risk information is more useful to investors when the firm is perceived to be more risky. 


\section{[Insert Table 8]}

\section{4 A change specification}

Our results may suffer from potentially correlated omitted variables and reverse causality issues. In an effort to address these concerns, we follow Li (2010a) and Kravet and Muslu (2013) by employing a change specification as follows:

$$
\begin{aligned}
\Delta \mathrm{SYNCH}_{\mathrm{t}+1}= & \alpha+\beta_{1} \Delta \mathrm{R}_{-} \mathrm{DISC}_{\mathrm{t}}+\beta_{2} \Delta \mathrm{SIZE}_{\mathrm{t}}+\beta_{3} \Delta \mathrm{LEV}_{\mathrm{t}}+\beta_{4} \Delta \mathrm{VOL}_{\mathrm{t}}+\beta_{5} \Delta \mathrm{STDROA}_{\mathrm{t}} \\
& +\beta_{6} \mathbb{B} / \mathrm{M}+{ }_{7} \beta \quad \Delta \mathrm{W} \mathrm{N} \mathrm{C}_{\mathrm{t}} \mathrm{EN}_{8} \beta \quad \mathrm{B} \mathrm{I} \mathrm{G}_{9} \beta \\
& +\beta_{10} \Delta \mathrm{BSIZE}_{\mathrm{t}}+\beta_{11} \Delta \text { DIND }_{\mathrm{t}}+\text { Year+Industry+ } \varepsilon_{\mathrm{t}}
\end{aligned}
$$

where $\triangle S Y N C H$ is the change in stock price synchronicity with $S Y N C H$ estimated based on Eq.(1), $\triangle R \_D I S C$ is the change in the total risk disclosure score, $\triangle S I Z E$ is the change in firm size, $\triangle L E V$ is the change in the leverage ratio, $\triangle V O L$ is the change in trading volume turnover, $\triangle S T D R O A$ is the change in earnings volatility, $\triangle B / M$ is the change in the book-to-market ratio, $\triangle O W N C E N$ is the change in ownership concentration, $\triangle B S I Z E$ is the change in board size, and $\triangle D I N D$ is the change in the percentage of independent directors. All the changes are computed on an annual basis.

Table 9 presents the results of the change specification. For the full sample, as reported in Panel A, the coefficient on $\triangle R_{-} D I S C$ is negative but insignificant (-0.056, $\mathrm{t}$-stat=-0.940). Turning to the subsample analysis, we find that the $\Delta R_{-} D I S C$ coefficients are significantly lower among IOFs $(-0.313$, t-stat=-2.170) than DOFs $(0.000, \mathrm{t}-\mathrm{stat}=0.000)$. Once again, the coefficient differs significantly between the two subsamples $(\mathrm{t}=-2.57)$. This further confirms the prediction of $\mathrm{H} 2$.

[Insert Table 9]

\subsection{Two-stage least squares approach}

Thus far, we have assumed that risk disclosure is exogenous to stock price synchronicity. However, both the level of risk disclosure and stock price synchronicity may depend on unobserved firm characteristics, which would in turn lead to biased 
estimators. To further enhance the robustness of our evidence, we employ a two-stage least squares (2SLS) approach and repeat our main analyses. In the first stage, we regress $R \_D I S C$ on the existent control variables along with two newly introduced instrumental variables (IV). The first IV we apply is CEO gender, which is a dummy variable taking a value of one if the CEO is female and zero otherwise. As suggested by Faccio et al. (2012), female CEOs display a lower propensity for risk taking, and are therefore expected to disclose more risk factors to mitigate uncertainty. The second IV is CEO age, which is a continuous variable measured as the CEO's age as of the fiscal year end. Following Tasker (1998), who argues that younger CEOs are more likely to disclose information because they are expected to invest more in signaling their ability to outsiders than their counterparts who are closer to retirement, we expect a negative coefficient on this variable in the first-stage regression. However, both CEO gender and age are unlikely to have direct impacts on stock price synchronicity, which makes them valid IVs for 2SLS estimation.

Table 10 presents just the second-stage results, for brevity. In the first-stage estimation, the untabulated results show that the coefficients on CEO gender are significantly positive (full sample: $0.045, \mathrm{t}$-stat=2.07), while those on CEO age are significantly negative (full sample: -0.003 , $\mathrm{t}-\mathrm{stat}=-4.55$ ). A further test of the linear combination of the IVs suggests that the two IV estimators are efficient (F-stat $=3.75$, p-value $<0.1)$. In the second-stage estimation, when $\operatorname{SYNCH(1)}$ is the dependent variable, $R \_D I S C$ is negatively associated with stock price synchronicity $(-0.159$, $\mathrm{t}$-stat=-3.66). In addition, the negative effect of risk disclosure on price synchronicity is more pronounced among IOFs $(-0.430$, $\mathrm{t}$-stat=-3.86) than DOFs $(-0.098$, t-stat=-2.07). The coefficients on $R_{-} D I S C$ differ significantly between the two subsamples ( $\mathrm{t}-\mathrm{stat}=-2.88)$. The findings are robust to the use of the alternative measure of stock price synchronicity $(\operatorname{SYNCH}(2))$. Finally, the results of the Sargan-Hansen test reveal that over-identification is not a concern in the present study.

[Insert Table 10] 


\subsection{Do internationally oriented firms disclose more risk factors?}

The above findings consistently show that international orientation facilitates the capturing of disclosed firm-specific risk information in stock prices. The underlying argument is that IOFs are likely to disclose more risk factors than DOFs in order to mitigate the concerns of investors who are reluctant to invest in risky assets. To empirically investigate the argument, we estimate the model as follows:

$$
\begin{aligned}
R_{-} D I S C_{t} & =\alpha_{0}+\alpha_{1} \text { INTER }_{t} \text { or INTER_D } D_{t}+\alpha_{2} R_{-} D I S C_{t-1}+\alpha_{3} \text { SIZE }_{t}+\alpha_{4} L_{E V} \\
& +\alpha_{5} \text { ROA }_{t}+\alpha_{6} B / M_{t}+\alpha_{7} \text { OWNCEN }_{t}+\alpha_{8} \text { BIG }_{t}+\alpha_{9} D I N D_{t} \\
& +\alpha_{10} \text { BETA }_{t}+\alpha_{11} \text { RET }_{t}+\alpha_{12} \text { TURN }_{t}+\alpha_{13} \text { STATE }_{t}+\text { Industry } \\
& + \text { Year }+\varepsilon_{t}
\end{aligned}
$$

where $R \_D I S C_{t}$ is measured as the total score for risk disclosure in year t. INTER is a dummy variable that equals one if foreign sales account for at least $25 \%$ of total sales. INTER_D is an alternative measure of international orientation, which takes a value of one if the firm's foreign sales are greater than zero. If IOFs disclose more risk factors, then we should observe a positive and significant $\alpha_{1}$.

Following prior literature (Dhaliwal et al., 2011; Campbell et al., 2014), we control for a number of factors that may also affect risk disclosure. Since a firm's disclosure behavior tends to persist over time, a variable that indicates the extent of risk disclosure in year $\mathrm{t}-1\left(R \_D I S C_{t-1}\right)$ is included. Thus, the coefficient on $R \_D I S C_{t-1}$ will be positive. We control for firm size (SIZE) because size is considered to affect a firm's reporting incentives. On the one hand, larger firms face greater public pressure and regulatory scrutiny (Watts and Zimmerman, 1986) and will thus be more likely to disclose risk factors. Therefore, we would expect a positive coefficient on SIZE. On the other hand, however, larger firms tend to have lower risks (Fama and French, 1993) and will thus be less likely to disclose risk factors. If this were true, we would expect the coefficient on SIZE to be negative. Taking these arguments together, the coefficient on SIZE is unknown ex ante (Campbell et al., 2014). We expect a positive coefficient on the leverage ratio ( $L E V)$ because heavy leverage increases firms' business risk, which in turn induces firms to disclose risk information to lower the risk. 
We expect the coefficient on $R O A$ to be positive if better-performing firms have more financial resources for disclosing risk. However, more profitable firms may face less risk, which may lead to a negative coefficient on $R O A$. Therefore, we do not make a prediction about the sign of the coefficient on $R O A$. The coefficient on the book-to-market ratio $(B / M)$ is unpredictable as well. The coefficient may be negative if growth opportunities are positively associated with firm risk as suggested by Fama and French (1993). However, if investors perceive firms with a high $B / M$ as more risky, then we would expect a positive coefficient on $B / M$.

Agency theory suggests that managers may voluntarily disclose information as a means to reduce agency conflict with the owners when shares are widely owned (Craswell and Taylor, 1992). However, in a dispersed ownership structure, shareholders are less able to influence a firm's reporting practices (Barako et al., 2006). Thus, the sign of the coefficient on ownership concentration (OWNCEN) cannot be predicted. We expect a positive coefficient on BIG4 because big four audit firms will require their clients to disclose more risk information due to a greater litigation risk (Lennox, 1999). We also expect the coefficient on DIND to be positive because independent directors act as an effective mechanism for curb agency problems (Fama and French, 1983) and thus positively affect a firm's reporting practice.

Since the market beta is typically used to measure firm risk, the coefficient on BETA should be positively associated with risk factor disclosure (Campbell et al., 2014). In our study, BETA is taken from the CSMAR database. In addition, the coefficient on RET should be positive because the realized returns are often deemed a proxy for the cost of capital (Vuolteenaho, 2002). RET is measured as the annual stock return over the period beginning in the $5^{\text {th }}$ month of the fiscal year and ending in the $4^{\text {th }}$ month after fiscal year end. TURN should also be positively associated with risk factor disclosure because turnover is a proxy for information asymmetry (Jiang et al., 2005). TURN is computed using the average daily share turnover ratio during the fiscal year. Finally, we control for state ownership (STATE) because it increases moral hazard and agency problems, which in turn may discourage risk factor disclosure. 
STATE is defined as the number of shares held by the government.

Table 11 presents the regression results. Both measures of international orientation are positively associated with risk disclosure and significant at the $1 \%$ level, which is in line with our argument that IOFs tend to disclose more risk factors due to greater uncertainty. In addition, the signs of the coefficients on the control variables are broadly as expected, which further enhances the validity of our risk disclosure measures. For example, the coefficient on $R \_D I S C_{t-1}$ is significantly positive, suggesting that a firm's disclosure practices are persistent over time. The coefficients on BETA are significantly positive, implying that firms with greater business risk are likely to disclose more risk factors to mitigate uncertainty. TURN has positive and significant coefficients as expected, suggesting that firms with greater information uncertainty are more likely to disclose risk factors. STATE is negatively associated with risk disclosure, consistent with the notion that government ownership leads to greater agency conflict and subsequently a lower level of disclosure.

[Insert Table 11]

\section{Conclusions}

In this paper we examine the association between stock price informativeness and the extent of risk disclosure in China. Using a sample of Chinese listed firms for the period 2007-2011, we obtain the following findings: First, there is a negative association between stock price synchronicity and risk disclosure. This is consistent with risk disclosure being useful and informative for investors. Furthermore, the association is more pronounced among IOFs, because international diversification increases the complexity and risk involved. As a result, such firms are likely to disclose more firm-specific risk factors to mitigate the concerns of investors. A further investigation finds that IOFs are likely to disclose more risk factors than their domestically oriented counterparts. Our findings are robust to alternative specifications and alternative measures of risk disclosure, stock price synchronicity and international orientation.

Our findings have implications for policy makers, investors and firms. For policy 
makers, the increasing importance and usefulness of risk disclosure has spurred the stock market regulators to improve the reliability of risk information. Our empirical evidence largely suggests that firms tend to reveal credible information in the narrative sections of their annual reports. Policy makers, though, might encourage DOFs to exhibit more meaningful risk information in narrative sections. This is particularly the case given the increasing economic interdependence of national economies across the world, which relates to greater complexity and difficulties in understanding the information of multinational firms. In addition, investors can benefit from our study through an increased awareness of the association between information asymmetry and risk disclosure. Moreover, our findings may help them to develop more effective trading strategies. Investors might rely on our findings to form expectations about the informativeness of risk disclosure across DOFs and IOFs. Finally, firms can utilize the results to improve the information environment and reduce the information-asymmetric component of stock prices. Additionally, firms should now be aware of market expectations regarding their risk disclosure, enabling the market to distinguish firms that disclose meaningful risk information from those whose disclosure is less informative or nonexistent.

Our study provides potential avenues for future research. First, our findings suggest that risk disclosure conveys firm-specific information to investors. Future studies can investigate whether and how risk disclosure affects the capital constraints or investment efficiency of public firms. Second, our study implies that international diversification enhances the incorporation of firm-specific risk factors into stock prices. Future research can examine how financial intermediaries such as analysts and the business press interact with risk disclosure information to affect stock price informativeness. Lastly, in the present study, our risk disclosure measures are limited to the information in annual reports. It might be worth exploring the economic consequences of risk factors disclosed in other documents such as press releases and/or conference calls. 


\section{Reference}

Abraham, S., \& Cox, P. (2007). Analysing the determinants of narrative risk information in UK FTSE 100 annual reports. The British Accounting Review, $39(3), 227-248$.

ACCA. (2011a), Beyond Numbers, What Do Investors Need? http://www2.accaglobal.com/pdfs/beyondnumbers_en

Barako, D. G., Hancock, P., \& Izan, H. Y. (2006). Factors influencing voluntary corporate disclosure by Kenyan companies. Corporate Governance: An International Review, 14(2), 107-125.

Barry, C., \& Brown, S. J. (1985). Differential information and security market equilibrium. Journal of Financial and Quantitative Analysis, 20(4), 407-422.

Barth, M., Landsman, W. (2010). How did financial reporting contribute to the financial crisis? Working Paper,

Beretta, S., \& Bozzolan, S. (2004). A framework for the analysis of firm risk communication. The International Journal of Accounting, 39(3), 265-288.

Bodnar, G. M., \& Weintrop, J. (1997). The valuation of the foreign income of US multinational firms: A growth opportunities perspective. Journal of Accounting and Economics, 24(1), 69-97.

Brown, S., \& Hillegeist, S. A. (2007). How disclosure quality affects the level of information asymmetry. Review of Accounting Studies, 12(2-3), 443-477.

Cahan, S. F., Rahman, A., \& Perera, H. (2005). Global diversification and corporate disclosure. Journal of International Accounting Research, 4(1), 73-93.

Campbell, J., Chen, H., Dhaliwal, D. S., Lu, H. M., \& Steele, L. (2014). The information content of mandatory risk factor disclosures in corporate filings. Review of Accounting Studies, 19(1), 396-455

Caskey, J. A. (2009). Information in equity markets with ambiguity-averse investors. Review of Financial Studies, 22(9), 3595-3627.

Chan, K., \& Hameed, A. (2006). Stock price synchronicity and analyst coverage in emerging markets. Journal of Financial Economics, 80(1), 115-147.

Chen, K. H., \& Metcalf, R. W. (1980). The relationship between pollution control record and financial indicators revisited. The Accounting Review, 55(1), 168-177.

Cheung, Y. L., Jiang, P., \& Tan, W. (2010). A transparency Disclosure Index measuring disclosures: Chinese listed companies. Journal of Accounting and Public Policy, 29(3), 259-280.

China Securities Regulatory Commission (CSRC). (1996). Announcement of some rules on the issuance of shares.

China Securities Regulatory Commission (CSRC). (2005). Guideline on Contents and Formats of Information Disclosure by the Companies That Make Public Offering of Securities No.2-Contents and Formats of Annual Reports. No.141

China Securities Regulatory Commission (CSRC). (2012). The Standards Concerning the Content and Formats of Information Disclosure by Companies Offering Securities to the Public No.2 -Contents and Formats of Annual Reports. No.22

Craswell, A. T., \& Taylor, S. L. (1992). Discretionary disclosure of reserves by oil and gas companies: an economic analysis. Journal of Business Finance \& Accounting, 19(2), 295-308.

Dhaliwal, D. S., Li, O. Z., Tsang, A., \& Yang, Y. G., 2011. Voluntary nonfinancial 
disclosure and the cost of equity capital: the initiation of corporate social responsibility reporting. The Accounting Review, 86(1), 59-100.

Diamond, D. W., \& Verrecchia, R. E. (1991). Disclosure, liquidity, and the cost of capital. The Journal of Finance, 46(4), 1325-1359.

Ding, R., \& Cheng, P. (2011). Speculative trading, price pressure and overvaluation. Journal of International Financial Markets, Institutions and Money, 21(3), 419-442.

Ding, R., Hou, W., Kuo, J. M., \& Lee, E. (2013). Does analyst coverage affect share price informativeness of Chinese listed firms? Working Paper

Dobler, M., Lajili, K., \& Zéghal, D. (2011). Attributes of corporate risk disclosure: an international investigation in the manufacturing sector. Journal of International Accounting Research, 10(2), 1-22.

Durnev, A., Morck, R., Yeung, B., \& Zarowin, P. (2003). Does greater firm-specific return variation mean more or less informed stock pricing? Journal of Accounting Research, 41(5), 797-836.

Duru, A., \& Reeb, D. M. (2002). International diversification and analysts' forecast accuracy and bias. The Accounting Review, 77(2), 415-433.

Easley, D., \& O'hara, M. (2004). Information and the cost of capital. The Journal of Finance, 59(4), 1553-1583.

Economist. (2011). How to get a date. http://www.economist.com/node/21542155

Elshandidy, T., Fraser, I., \& Hussainey, K. (2013). Aggregated, voluntary, and mandatory risk disclosure incentives: Evidence from UK FTSE all-share companies. International Review of Financial Analysis, 30, 320-333.

Elshandidy, T., Fraser, I., \& Hussainey, K. (2015). What drives mandatory and voluntary risk reporting variations across Germany, UK and US?. The British Accounting Review, 47(4), 376-394.

Elshandidy, T., \& Neri, L. (2015). Corporate governance, risk disclosure practices, and market liquidity: comparative evidence from the UK and Italy. Corporate Governance: An International Review, 23(4), 331-356.

Faccio, M., Marchica, M. T., \& Mura, R. (2012). CEO gender, corporate risk-taking, and the efficiency of capital allocation. Available at SSRN 2021136.

Fama, E., \& French, K. (1993). Common risk factors in the returns on stock and bonds. Journal of Financial Economics, 33, 3-56.

Glaeser, E., Johnson, S., \& Shleifer, A. (2001). Coase versus the Coasians. The Quarterly Journal of Economics, 116(3), 853-899.

Gray, S. J., Meek, G. K., \& Roberts, C. B. (1995). International capital market pressures and voluntary annual report disclosures by US and UK multinationals. Journal of International Financial Management \& Accounting, 6(1), 43-68.

Gul, F. A., Kim, J. B., \& Qiu, A. A. (2010). Ownership concentration, foreign shareholding, audit quality, and stock price synchronicity: Evidence from China. Journal of Financial Economics, 95(3), 425-442.

He, J., \& Ng, L. K. (1998). The foreign exchange exposure of Japanese multinational corporations. The Journal of Finance, 53(2), 733-753.

Hodder, L., McAnally, M.L. (2001). SEC market-risk disclosures: enhancing comparability. Financial Analysts Journal, 57(2), 24-34. 
Huang, K. W. (2013). Exploring the Information Contents of Risk Factors in SEC Form 10-K: A Multi-Label Text Classification Application. Working Paper, National University of Singapore.

Jiang, G., Lee, C., \& Zhang, Y. (2005). Information uncertainty and expected returns. Review of Accounting Studies, 10, 185-221.

Johnson, S. (2010). SEC pushes companies for more risk information. CFO Magazine, August 2.

Jorgensen, B. N., \& Kirschenheiter, M. T. (2003). Discretionary risk disclosures. The Accounting Review, 78(2), 449-469.

Jorion, P. (2002). How informative are value at risk disclosures? Accounting Review, 77(4), 911-931.

Kim, H., \& Yasuda, Y. (2013). A new approach to identify the economic effects of disclosure: Information content of business risk disclosures in Japanese firms. Working Paper, Tokyo Keizai University.

Kim, J. B., \& Shi, H. (2012). IFRS reporting, firm-specific information flows, and institutional environments: international evidence. Review of Accounting Studies, 17(3), 474-517.

Kim, J. B., Li, Y., \& Zhang, L. (2011a). Corporate tax avoidance and stock price crash risk: Firm-level analysis. Journal of Financial Economics, 100(3), 639-662.

Kim, J. B., Li, Y., \& Zhang, L. (2011b). CFOs versus CEOs: Equity incentives and crashes. Journal of Financial Economics, 101(3), 713-730.

Kim, O., \& Verrecchia, R. E. (1994). Market liquidity and volume around earnings announcements. Journal of Accounting and Economics, 17(1), 41-67.

Knight, G. A., \& Kim, D. (2008). International business competence and the contemporary firm. Journal of International Business Studies, 40(2), 255-273.

Koster, S., \& Karlsson, C. (2009). New firm formation and economic development in a globalizing economy. Working Paper.

Kothari, S. P., Li, X., \& Short, J. E. (2009). The effect of disclosures by management, analysts, and business press on cost of capital, return volatility, and analyst forecasts: a study using content analysis. The Accounting Review, 84(5), 1639-1670.

Kravet, T., \& Muslu, V. (2013). Textual risk disclosures and investors' risk perceptions. Review of Accounting Studies, 18(4), 1088-1122.

La Porta, R., Lopez-de-Silanes, F., Shleifer, A., Vishny, R. (1998). Law and finance. Journal of Political Economy, 106(6), 1113-1155.

Lennox, C. S. (1999). Non-audit fees, disclosure and audit quality. European Accounting Review, 8(2), 239-252.

Lev, B. (1988). Toward a theory of equitable and efficient accounting policy. The Accounting Review, 1-22.

Li, F. (2010a). Textual analysis of corporate disclosures: A survey of literature. Journal of Accounting Literature, 29, 143-165.

Lim, C. Y., \& Tan, P. M. S. (2007). Value relevance of value-at-risk disclosure. Review of Quantitative Finance and Accounting, 29(4), 353-370.

Lind, D. A., Marchal, W. G., Mason, R. D., 2002. Statistical techniques in business and economics. MaGraw-Hill, Irwin.

Linsley, P. M., \& Shrives, P. J. (2006). Risk reporting: A study of risk disclosures in 
the annual reports of UK companies. The British Accounting Review, 38(4), 387-404.

Linsmeier, T., Thornton, D., Venkatachalam, M., Welker, M. (2002). The effect of mandated market risk disclosure on trading volume sensitivity to interest rate, exchange rate, and commodity price movements. Accounting Review, 77(2), 343-377.

Madura, J. (1992). International financial management (Vol. 188). West Publishing Company.

Marshall, A. P., \& Weetman, P. (2002). Information asymmetry in disclosure of foreign exchange risk management: can regulation be effective? Journal of Economics and Business, 54(1), 31-53.

Michel, A., \& Shaked, I. (1986). Multinational corporations vs. domestic corporations: Financial performance and characteristics. Journal of International Business Studies, 89-100.

Miihkinen, A. (2012). What Drives Quality of Firm Risk Disclosure? The Impact of a National Disclosure Standard and Reporting Incentives under IFRS. The International Journal of Accounting, 47, 437-468.

Miihkinen, A. (2013). The usefulness of firm risk disclosures under different firm riskiness, investor-interest, and market conditions: New evidence from Finland. Advances in Accounting, 312-331.

Morck, R., Yeung, B., \& Yu, W. (2000). The information content of stock markets: why do emerging markets have synchronous stock price movements? Journal of Financial Economics, 58(1), 215-260.

Neimark, M. D. (1992). The hidden dimensions of annual reports. London: Paul Chapman.

Nobes, C. W. (1998). Towards a general model of the reasons for international differences in financial reporting. Abacus, 34(2): 162-187.

O'Connor, N. G., Vera-Munoz, S. C., \& Chan, F. (2009). The effects of market competition and international orientation on management control systems' use by emerging market publicly listed companies. Working Paper.

Olibe, K. O., Michello, F. A., \& Thorne, J. (2008). Systematic risk and international diversification: An empirical perspective. International Review of Financial Analysis, 17(4), 681-698.

Piotroski, J. D., \& Roulstone, D. T. (2004). The influence of analysts, institutional investors, and insiders on the incorporation of market, industry, and firm-specific information into stock prices. The Accounting Review, 79(4), 1119-1151.

Rajgopal, S. (1999). Early evidence on the informativeness of the SEC's market risk disclosures: The case of commodity price risk exposure of oil and gas producers. The Accounting Review, 74(3), 251-280.

Reeb, D. M., Kwok, C. C., \& Baek, H. Y. (1998). Systematic risk of the multinational corporation. Journal of International Business Studies, 263-279.

Roulstone, D. T. (1999). Effect of SEC financial reporting release No. 48 on derivative and market risk disclosures. Accounting Horizons, 13(4), 343-363.

Schipper, K. (2007). Required disclosures in financial reports. The Accounting Review, 82(2), 301-326.

Shapiro, A. C. (1978). Financial structure and cost of capital in the multinational 
corporation. Journal of Financial and Quantitative Analysis, 13(2), 211-226.

Sullivan, D. (1994). Measuring the degree of internationalization of a firm. Journal of International Business Studies, 325-342.

Tasker, S. C. (1998). Bridging the information gap: Quarterly conference calls as a medium for voluntary disclosure. Review of Accounting Studies, 3(1-2), 137-167.

Thomas, W. B. (1999). A test of the market's mispricing of domestic and foreign earnings. Journal of Accounting and Economics, 28(3), 243-267.

Verrecchia, R. E. (2001). Essays on disclosure. Journal of Accounting and Economics, 32(1), 97-180.

Vuolteenaho, T. (2002). What drives firm-level stock returns? Journal of Finance, 57, 233-264.

Watts, R., Zimmerman, J., 1986, Positive accounting theory (Prentice Hall, Englewood Cliffs, NJ).

Xu, N., Li, X., Yuan, Q., \& Chan, K. C. (2014). Excess perks and stock price crash risk: Evidence from China. Journal of Corporate Finance, 25, 419-434. 
Table 1: Sample distribution

\begin{tabular}{|c|c|c|c|c|c|c|}
\hline \multicolumn{7}{|l|}{ Panel A: Industry distribution } \\
\hline \multicolumn{2}{|l|}{ Industry } & \multicolumn{2}{|l|}{$\underline{\text { CSRC code }}$} & \# of firm-years & \multicolumn{2}{|c|}{$\%$ of firm-years } \\
\hline \multirow{2}{*}{\multicolumn{2}{|c|}{$\begin{array}{l}\text { Agriculture, Forestry, and Fishing } \\
\text { Mining }\end{array}$}} & \multicolumn{2}{|l|}{ A } & 114 & \multicolumn{2}{|c|}{2.098} \\
\hline & & \multicolumn{2}{|l|}{ B } & 140 & \multicolumn{2}{|c|}{2.577} \\
\hline Manufacturing & & \multicolumn{2}{|l|}{$\mathrm{C}$} & 3,028 & \multicolumn{2}{|c|}{55.733} \\
\hline Utilities & & \multirow{2}{*}{\multicolumn{2}{|c|}{$\mathrm{D}$}} & 261 & \multicolumn{2}{|c|}{4.804} \\
\hline Construction & & \multirow{2}{*}{\multicolumn{2}{|c|}{$\begin{array}{l}\mathrm{E} \\
\mathrm{F}\end{array}$}} & 127 & \multicolumn{2}{|c|}{2.338} \\
\hline Transportation & & & & 247 & \multicolumn{2}{|c|}{4.546} \\
\hline Information Technology & & \multicolumn{2}{|l|}{$\mathrm{G}$} & 313 & \multicolumn{2}{|c|}{5.761} \\
\hline Trade & & \multicolumn{2}{|l|}{$\mathrm{H}$} & 376 & \multicolumn{2}{|c|}{6.921} \\
\hline Real Estate & & \multirow{2}{*}{\multicolumn{2}{|c|}{$\begin{array}{l}\mathrm{J} \\
\mathrm{K}\end{array}$}} & 352 & \multirow{2}{*}{\multicolumn{2}{|c|}{$0.4 / 9$}} \\
\hline Service & & & & 163 & & \\
\hline Media & & \multicolumn{2}{|l|}{$\mathrm{L}$} & 46 & \multicolumn{2}{|c|}{0.847} \\
\hline Others & & M & & 266 & & \\
\hline Total & & & & 5,433 & & \\
\hline Panel B: Yearly distribution & & & & & & \\
\hline & 2007 & & 2008 & 2009 & 2010 & 2011 \\
\hline \# of firm-years & 892 & & 943 & 1,001 & 1,287 & 1,310 \\
\hline$\%$ of firm-years & 16.418 & & 17.357 & 18.424 & 23.689 & 24.112 \\
\hline
\end{tabular}

This table presents the sample distribution by industry (Panel A) and by year (Panel B). CSRC is the China Securities Regulatory Commission. 
Table 2: Descriptive statistics

\begin{tabular}{|c|c|c|c|c|c|}
\hline \multicolumn{6}{|c|}{ Panel A: Full sample analysis } \\
\hline Variable & Mean & Median & Std. Dev. & Min & Max \\
\hline SYNCH(1) & -0.489 & -0.387 & 1.110 & -4.430 & 1.678 \\
\hline SYNCH(2) & 0.039 & 0.076 & 0.943 & -2.580 & 2.125 \\
\hline R_DISC & 0.519 & 0.500 & 0.334 & 0.000 & 1.000 \\
\hline NUM_RDISC & 1.812 & 1.946 & 1.048 & 0.000 & 3.970 \\
\hline INTER & 0.156 & 0.000 & 0.363 & 0.000 & 1.000 \\
\hline INTER_D & 0.460 & 0.000 & 0.498 & 0.000 & 1.000 \\
\hline SIZE & 21.885 & 21.757 & 1.179 & 18.724 & 25.334 \\
\hline LEV & 0.509 & 0.518 & 0.187 & 0.078 & 1.262 \\
\hline VOL & 23.670 & 23.636 & 0.822 & 21.433 & 25.830 \\
\hline STDROA & 0.028 & 0.016 & 0.042 & 0.001 & 0.576 \\
\hline $\mathrm{B} / \mathrm{M}$ & 0.634 & 0.620 & 0.260 & 0.094 & 1.231 \\
\hline OWNCEN & 0.362 & 0.345 & 0.153 & 0.085 & 0.750 \\
\hline BIG4 & 0.054 & 0.000 & 0.226 & 0.000 & 1.000 \\
\hline DUALITY & 0.133 & 0.000 & 0.340 & 0.000 & 1.000 \\
\hline BSIZE & 9.205 & 9.000 & 1.850 & 5.000 & 15.000 \\
\hline DIND & 0.364 & 0.333 & 0.050 & 0.273 & 0.556 \\
\hline
\end{tabular}

Panel B: Subsample analyses

\begin{tabular}{|c|c|c|c|c|c|c|}
\hline \multirow[b]{2}{*}{ Variable } & \multicolumn{3}{|c|}{ Mean } & \multicolumn{3}{|c|}{ Median (Percentage) } \\
\hline & $\begin{array}{c}\text { International } \\
(\text { Obs. }=849)\end{array}$ & $\begin{array}{c}\text { Domestic } \\
(\text { Obs. }=4,584)\end{array}$ & $\begin{array}{c}\text { Difference } \\
\text { t-stat }\end{array}$ & $\begin{array}{l}\text { International } \\
(\text { Obs. }=849)\end{array}$ & $\begin{array}{c}\text { Domestic } \\
(\text { Obs. }=4,584)\end{array}$ & $\begin{array}{c}\text { Difference } \\
\text { t-stat }\end{array}$ \\
\hline SYNCH(1) & -0.596 & -0.470 & $3.035 * * *$ & -0.475 & -0.367 & $2.884 * * *$ \\
\hline $\operatorname{SYNCH}(2)$ & -0.079 & 0.061 & $3.990 * * *$ & -0.055 & 0.098 & $4.048 * * *$ \\
\hline R_DISC & 0.541 & 0.515 & $-2.143 * *$ & 0.500 & 0.500 & $-1.924 *$ \\
\hline NUM_RDISC & 1.876 & 1.810 & $-1.697 *$ & 2.079 & 1.946 & $-1.923 *$ \\
\hline SIZE & 21.768 & 21.906 & $3.132 * * *$ & 21.655 & 21.786 & $3.384 * * *$ \\
\hline LEV & 0.488 & 0.513 & $3.503 * * *$ & 0.497 & 0.523 & $3.363 * * *$ \\
\hline VOL & 23.610 & 23.681 & $2.309 * *$ & 23.560 & 23.650 & $2.152 * *$ \\
\hline STDROA & 0.029 & 0.028 & -0.812 & 0.017 & 0.016 & $-1.840 *$ \\
\hline $\mathrm{B} / \mathrm{M}$ & 0.610 & 0.638 & $2.891 * * *$ & 0.589 & 0.629 & $2.903 * * *$ \\
\hline OWNCEN & 0.358 & 0.363 & 0.937 & 0.355 & 0.343 & 0.165 \\
\hline BIG4 & 0.042 & 0.056 & $2.937 * * *$ & 0.000 & 0.000 & 2.620 \\
\hline DUALITY & 0.147 & 0.130 & $2.479 * * *$ & 0.000 & 0.000 & 1.747 \\
\hline BSIZE & 9.104 & 9.223 & $1.732 *$ & 9.000 & 9.000 & 1.599 \\
\hline DIND & 0.360 & 0.365 & $2.341 * *$ & 0.333 & 0.333 & $3.130 * * *$ \\
\hline
\end{tabular}

This table presents descriptive statistics of the variables used in the full sample analyses (Panel A) and subsample analyses (Panel B). The variables are defined as follows: $\boldsymbol{S Y N C H ( 1 )}$ is computed as $\log \left[\mathrm{R}^{2} /\left(1-\mathrm{R}^{2}\right)\right]$, where $\mathrm{R}^{2}$ is estimated based on Eq. (1) using the daily returns of the 30 trading days following the risk disclosure release dates. $\boldsymbol{S Y N C H ( 2 )}$ is computed as $\log \left[\mathrm{R}^{2} /\left(1-\mathrm{R}^{2}\right)\right]$, where $\mathrm{R}^{2}$ is estimated based on Eq. (2) using the daily returns of the 30 trading days following the risk disclosure release dates. $\boldsymbol{R} \_\boldsymbol{D I S C}$ is measured as the total score for risk disclosure. NUM_RDISC is computed as Log (1+ Number of sentences in the section on risk factors in the annual report). SIZE is the logarithm of total assets. $\boldsymbol{L E} \boldsymbol{V}$ is measured as total liabilities divided by total assets. $\boldsymbol{V O \boldsymbol { L }}$ is defined as the total number of shares traded in a year, divided by the total number of shares outstanding at the end of the fiscal year. STDROA is the standard deviation of a firm's ROA over the preceding five years, including the current year. B/M is measured as

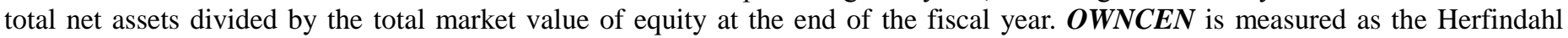
index of the top 10 shareholders. BIG4 is a dummy variable that equals one if the firm is audited by one of the Big 4 audit firms. DUALITY is a dummy variable that equals one if the CEO also serves as board chair, and zero otherwise. BSIZE is measured as the logarithm of the number of board members. DIND is the percentage of independent directors. A firm is classified as internationally oriented if the foreign sales account for $25 \%$ of the total sales (e.g., O'Conner et al., 2009; Knight and Cavusgil, 2004). All continuous variables are winsorized at the $1^{\text {st }}$ and $99^{\text {th }}$ percentiles. The dummy variables are not. *, **, and *** denote significance at the $10 \%, 5 \%$, and $1 \%$ levels (two-sided), respectively. 
Table 3: Correlation matrix

\begin{tabular}{|c|c|c|c|c|c|c|c|c|c|c|c|c|c|}
\hline & SYNCH(1) & SYNCH(2) & R_DISC & SIZE & LEV & VOL & STDROA & $\mathrm{B} / \mathrm{M}$ & OWNCEN & BIG4 & DUALITY & BSIZE & DIND \\
\hline \multicolumn{14}{|l|}{ SYNCH(1) } \\
\hline SYNCH(2) & 0.852 & & & & & & & & & & & & \\
\hline R_DISC & -0.060 & -0.037 & & & & & & & & & & & \\
\hline SIZE & 0.174 & 0.207 & -0.078 & & & & & & & & & & \\
\hline LEV & -0.006 & 0.003 & -0.064 & 0.367 & & & & & & & & & \\
\hline VOL & 0.206 & 0.238 & 0.027 & 0.534 & 0.038 & & & & & & & & \\
\hline STDROA & -0.072 & -0.080 & 0.002 & -0.152 & 0.017 & -0.023 & & & & & & & \\
\hline $\mathrm{B} / \mathrm{M}$ & 0.099 & 0.067 & -0.143 & 0.499 & 0.368 & -0.204 & -0.117 & & & & & & \\
\hline OWNCEN & 0.051 & 0.068 & -0.033 & 0.322 & 0.060 & 0.024 & -0.022 & 0.202 & & & & & \\
\hline BIG4 & 0.059 & 0.077 & -0.033 & 0.355 & 0.039 & 0.152 & -0.019 & 0.155 & 0.154 & & & & \\
\hline DUALITY & -0.043 & -0.047 & -0.009 & -0.120 & -0.092 & -0.031 & 0.007 & -0.112 & -0.082 & -0.034 & & & \\
\hline BSIZE & 0.060 & 0.090 & -0.038 & 0.288 & 0.115 & 0.159 & -0.057 & 0.109 & $\mathbf{0 . 0 3 8}$ & 0.114 & -0.121 & & \\
\hline DIND & -0.019 & -0.031 & -0.007 & 0.043 & -0.017 & 0.042 & 0.001 & 0.009 & 0.034 & 0.039 & 0.034 & -0.282 & \\
\hline
\end{tabular}

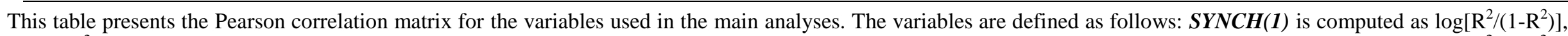
where $\mathrm{R}^{2}$ is estimated based on Eq. (1) using the daily returns of the 30 trading days following the risk disclosure release dates. $\boldsymbol{S Y N C H ( 2 )}$ is computed as log[ $\left.\mathrm{R}^{2} /\left(1-\mathrm{R}^{2}\right)\right]$, where $\mathrm{R}^{2}$ is estimated based on Eq. (2) using the daily returns of the 30 trading days following the risk disclosure release dates. $\boldsymbol{R} \_\boldsymbol{D I S C}$ is measured as the total score for risk

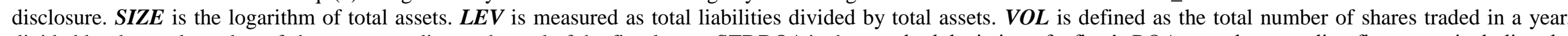
divided by the total number of shares outstanding at the end of the fiscal year. STDROA is the standard deviation of a firm's ROA over the preceding five years, including the current year. $\boldsymbol{B} / \boldsymbol{M}$ is measured as total net assets divided by the total market value of equity at the end of the fiscal year. $\boldsymbol{O W N C E N}$ is measured as the Herfindahl index of the top 10 shareholders. BIG4 is a dummy variable that equals one if the firm is audited by one of the Big 4 audit firms. DUALITY is a dummy variable that equals one if the CEO also serves as board chair, and zero otherwise. BSIZE is measured as the logarithm of the number of board members. DIND is the percentage of independent directors.

All continuous variables are winsorized at the $1^{\text {st }}$ and $99^{\text {th }}$ percentiles. The dummy variables are not. Bold numbers indicate significance at the $1 \%$ level. 
Table 4: The effect of risk disclosure on stock price synchronicity

\begin{tabular}{|c|c|c|c|c|}
\hline & \multicolumn{2}{|c|}{ Dependent=SYNCH(1) } & \multicolumn{2}{|c|}{ Dependent=SYNCH(2) } \\
\hline & (1a) & (1b) & $(2 a)$ & $(2 b)$ \\
\hline & Coef. & t-stat & Coef. & t-stat \\
\hline R_DISC & $-0.156 * * *$ & -3.590 & $-0.097 * * *$ & -2.770 \\
\hline SIZE & 0.026 & 1.050 & $0.111 * * *$ & 5.470 \\
\hline LEV & $-0.545 * * *$ & -6.190 & $-0.505 * * *$ & -7.090 \\
\hline VOL & $0.267 * * *$ & 9.350 & $0.146 * * *$ & 6.270 \\
\hline STDROA & $-1.085 * * *$ & -3.530 & $-1.173 * * *$ & -4.440 \\
\hline $\mathrm{B} / \mathrm{M}$ & $0.786 * * *$ & 8.820 & $0.391 * * *$ & 5.350 \\
\hline OWNCEN & -0.008 & -0.080 & -0.024 & -0.300 \\
\hline BIG4 & -0.073 & -1.290 & -0.027 & -0.550 \\
\hline DUALITY & -0.019 & -0.480 & -0.010 & -0.320 \\
\hline BSIZE & $-0.013 *$ & -1.650 & 0.000 & -0.060 \\
\hline DIND & -0.261 & -0.970 & $-0.411 *$ & -1.770 \\
\hline Constant & $-7.318 * * *$ & -16.210 & $-5.685 * * *$ & -15.520 \\
\hline Industry dummies & & & & \\
\hline Year dummies & & & & \\
\hline $\mathrm{N}$ & & & & \\
\hline $\operatorname{Adj} . R^{2}$ & & & & \\
\hline
\end{tabular}

This table presents the regression results of the effect of risk disclosure on stock price synchronicity. The variables are defined as follows: $\boldsymbol{S Y N C H}(1)$ is computed as $\log \left[\mathrm{R}^{2} /\left(1-\mathrm{R}^{2}\right)\right]$, where $\mathrm{R}^{2}$ is estimated based on Eq. (1) using the daily returns of the 30 trading days following the risk disclosure release dates. $\boldsymbol{S Y N C H ( 2 )}$ is computed as $\log \left[\mathrm{R}^{2} /\left(1-\mathrm{R}^{2}\right)\right]$, where $\mathrm{R}^{2}$ is estimated based on Eq. (2) using the daily returns of the 30 trading days following the risk disclosure release dates. $\boldsymbol{R} \_\boldsymbol{D I S C}$ is measured as the total score for risk disclosure. $\boldsymbol{S I Z E}$ is the logarithm of total assets. $\boldsymbol{L E} \boldsymbol{V}$ is measured as total liabilities divided by total assets. $\boldsymbol{V O L}$ is defined as the total number of shares traded in a year, divided by the total number of shares outstanding at the end of the fiscal year. STDROA is the standard deviation of a firm's ROA over the preceding five years, including the current year. $\boldsymbol{B} / \boldsymbol{M}$ is measured as total net assets divided by the total market value of equity at the end of the fiscal year. $\boldsymbol{O W N C E N}$ is measured as the Herfindahl index of the top 10 shareholders. BIG4 is a dummy variable that equals one if the firm is audited by one of the Big 4 audit firms. DUALITY is a dummy variable that equals one if the CEO also serves as board chair, and zero otherwise. BSIZE is measured as the logarithm of the number of board members. DIND is the percentage of independent directors. All continuous variables are winsorized at the $1^{\text {st }}$ and $99^{\text {th }}$ percentiles. The dummy variables are not. *, **, and *** denote significance at the $10 \%, 5 \%$, and $1 \%$ levels (two-sided), respectively. 
Table 5: The association between international orientation and informativeness of risk disclosure

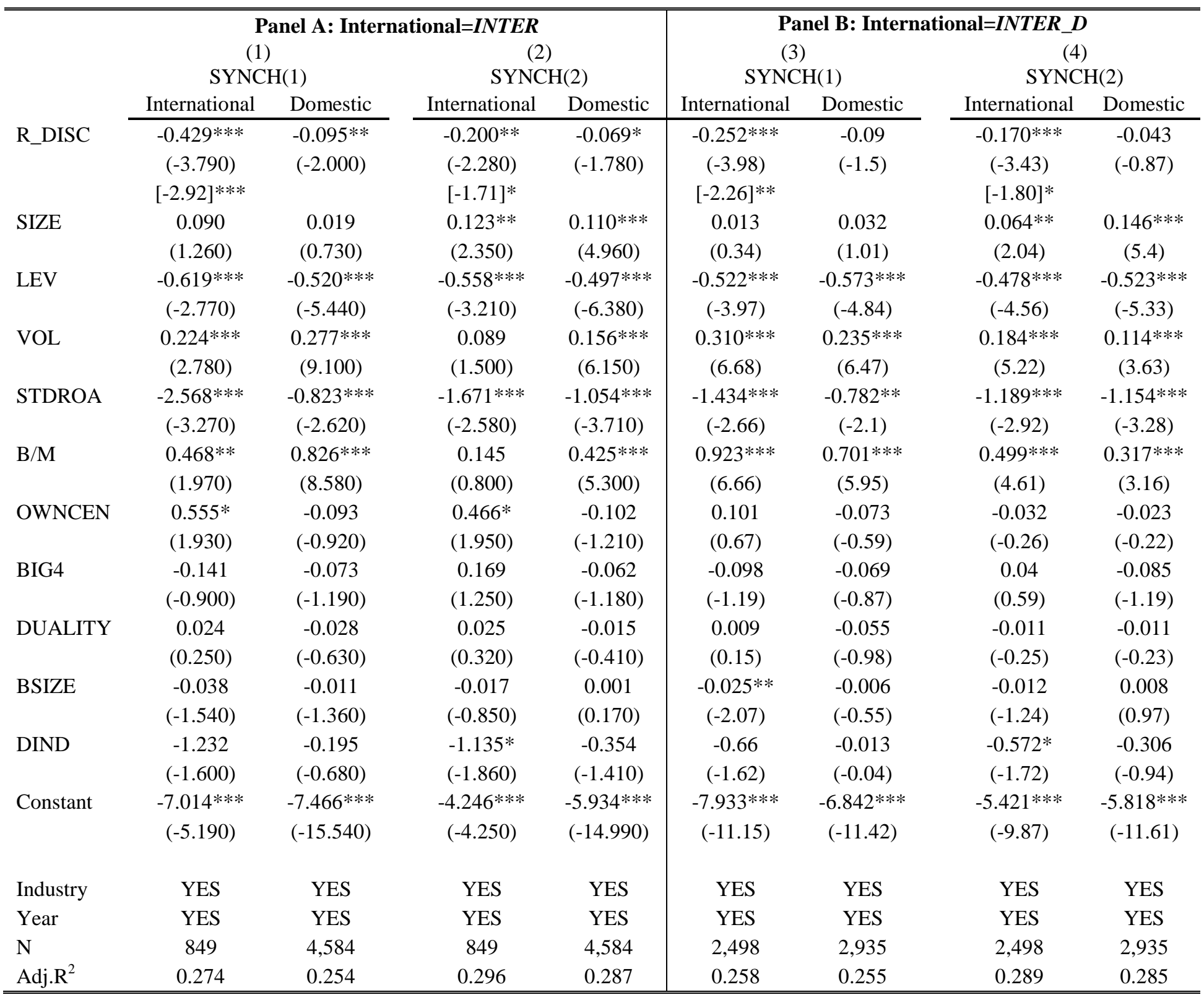

This table presents the regression results of the effect of risk disclosure on stock price synchronicity for the internationally oriented and domestically oriented subsamples, respectively. The variables are defined as follows: INTER is a dummy variable that equals one if the foreign sales account for $25 \%$ of the total sales. INTER_D is a dummy that equals one if the foreign sales are more than zero. SYNCH(1) is computed as $\log \left[\mathrm{R}^{2} /\left(1-\mathrm{R}^{2}\right)\right]$, where $\mathrm{R}^{2}$ is estimated based on Eq. (1) using the daily returns of the 30 trading days following the risk disclosure release dates. $S Y N \boldsymbol{C H}(2)$ is computed as $\log \left[\mathrm{R}^{2} /\left(1-\mathrm{R}^{2}\right)\right]$, where $\mathrm{R}^{2}$ is estimated based on Eq. (2) using the daily returns of the 30 trading days following the risk disclosure release dates. $\boldsymbol{R}_{-} \boldsymbol{D I S C}$ is measured as the total score for risk disclosure. SIZE is the logarithm of total assets. $\boldsymbol{L E} \boldsymbol{V}$ is measured as total liabilities divided by total assets. $\boldsymbol{V O \boldsymbol { L }}$ is defined as the total number of shares traded in a year, divided by the total number of shares outstanding at the end of the fiscal year. STDROA is the standard deviation of a firm's ROA over the preceding five years, including the current year. $\boldsymbol{B} / \boldsymbol{M}$ is measured as total net assets divided by the total market value of equity at the end of the fiscal year. OWNCEN is measured as the Herfindahl index of the top 10 shareholders. BIG4 is a dummy variable that equals one if the firm is audited by one of the Big 4 audit firms. DUALITY is a dummy variable that equals one if the CEO also serves as board chair, and zero otherwise. BSIZE is measured as the logarithm of the number of board members. DIND is the percentage of independent directors. All continuous variables are winsorized at the $1^{\text {st }}$ and $99^{\text {th }}$ percentiles. The dummy variables are not. The numbers reported in parentheses are the t-statistics for the coefficients. The numbers reported in square brackets are the t-statistics of the difference in the coefficients on $R \_D I S C$ between the two subsamples. *, **, and *** denote significance at the $10 \%, 5 \%$, and $1 \%$ levels (two-sided), respectively. 
Table 6: Alternative measure of risk disclosure and stock price synchronicity

\begin{tabular}{|c|c|c|c|c|c|c|}
\hline & \multicolumn{2}{|c|}{ Panel A: Full sample analysis } & \multicolumn{4}{|c|}{ Panel B: Subsample analysis } \\
\hline & \multirow[b]{2}{*}{ Coef. } & \multirow[b]{2}{*}{ t-stat } & \multicolumn{2}{|c|}{ International } & \multicolumn{2}{|c|}{ Domestic } \\
\hline & & & Coef. & t-stat & Coef. & t-stat \\
\hline NUM_RDISC & $-0.030 * *$ & -2.350 & $-0.148 * * *$ & -4.190 & $\begin{array}{c}-0.010 \\
{[3.35]^{* * *}}\end{array}$ & -0.700 \\
\hline SIZE & 0.027 & 1.080 & 0.073 & 1.020 & 0.020 & 0.760 \\
\hline LEV & $-0.542 * * *$ & -6.150 & $-0.754 * * *$ & -3.390 & $-0.515 * * *$ & -5.390 \\
\hline VOL & $0.268 * * *$ & 9.350 & 0.217 & 2.700 & $0.277 * * *$ & 9.080 \\
\hline STDROA & $-1.081 * * *$ & -3.480 & $-2.753 * * *$ & -3.490 & $-0.813 * * *$ & -2.570 \\
\hline $\mathrm{B} / \mathrm{M}$ & $0.811 * * *$ & 9.080 & $0.600 * *$ & 2.510 & $0.837 * * *$ & 8.690 \\
\hline OWNCEN & -0.004 & -0.040 & $0.578 * *$ & 2.010 & -0.094 & -0.940 \\
\hline BIG4 & -0.062 & -1.090 & -0.010 & -0.060 & -0.070 & -1.140 \\
\hline DUALITY & -0.014 & -0.340 & 0.092 & 0.950 & -0.026 & -0.600 \\
\hline BSIZE & -0.012 & -1.510 & -0.024 & -1.000 & -0.011 & -1.320 \\
\hline DIND & -0.229 & -0.850 & -0.855 & -1.130 & -0.185 & -0.640 \\
\hline Constant & $-7.432 * * *$ & -16.500 & $-6.780 * * *$ & -4.980 & $-7.536 * * *$ & -15.720 \\
\hline Industry dummies & \multicolumn{2}{|c|}{ YES } & \multicolumn{2}{|c|}{ YES } & \multicolumn{2}{|c|}{ YES } \\
\hline Year dummies & \multicolumn{2}{|c|}{ YES } & \multicolumn{2}{|c|}{ YES } & \multicolumn{2}{|c|}{ YES } \\
\hline $\mathrm{N}$ & \multicolumn{2}{|c|}{5,433} & \multicolumn{2}{|c|}{849} & \multicolumn{2}{|c|}{4,584} \\
\hline Adj. $R^{2}$ & \multicolumn{2}{|c|}{0.251} & \multicolumn{2}{|c|}{0.276} & \multicolumn{2}{|c|}{0.253} \\
\hline
\end{tabular}

This table presents the regression of the effects of alternative measure of risk disclosure on stock price synchronicity for the full sample (Panel A) and the subsamples (Panel B). A firm is classified as internationally oriented if foreign sales account for $25 \%$ of total sales (e.g., O'Conner et al., 2009; Knight and Cavusgil, 2004). The dependent variable used in this table is $\boldsymbol{S Y N C H}(\mathbf{1})$, computed as $\log \left[\mathrm{R}^{2} /\left(1-\mathrm{R}^{2}\right)\right]$, where $\mathrm{R}^{2}$ is estimated based on Eq. (1) using the daily returns of the 30 trading days following the risk disclosure release dates. The other variables are defined as follows: NUM_RDISC is computed as $\log (1+$ Number of sentences in the section on risk factors in the annual report). SIZE is the logarithm of total assets. $\boldsymbol{L E V}$ is measured as total liabilities divided by total assets. $\boldsymbol{V O \boldsymbol { L }}$ is defined as the total number of shares traded in a year, divided by the total number of shares outstanding at the end of the fiscal year. STDROA is the standard deviation of a firm's ROA over the preceding five years, including the current year. $\boldsymbol{B} / \boldsymbol{M}$ is measured as total net assets divided by the total market value of equity at the end of the fiscal year. $\boldsymbol{O W N C E N}$ is measured as the Herfindahl index of the top 10 shareholders. BIG4 is a dummy variable that equals one if the firm is audited by one of the Big 4 audit firms. DUALITY is a dummy variable that equals one if the CEO also serves as board chair, and zero otherwise. BSIZE is measured as the logarithm of the number of board members. DIND is the percentage of independent directors. All continuous variables are winsorized at the $1^{\text {st }}$ and $99^{\text {th }}$ percentiles. The dummy variables are not. The number reported in square brackets is the t-statistic of the difference in the coefficients on NUM_RDISC between the two subsamples. *, **, and *** denote significance at the $10 \%, 5 \%$, and $1 \%$ levels (two-sided), respectively. 
Table 7: The effect of industry-adjusted risk disclosure on stock price synchronicity

\begin{tabular}{|c|c|c|c|c|c|c|}
\hline & \multicolumn{2}{|c|}{ Panel A: Full sample analysis } & \multicolumn{4}{|c|}{ Panel B: Subsample analysis } \\
\hline & \multirow[b]{2}{*}{ Coef. } & \multirow[b]{2}{*}{ t-stat } & \multicolumn{2}{|c|}{ International } & \multicolumn{2}{|c|}{ Domestic } \\
\hline & & & Coef. & t-stat & Coef. & t-stat \\
\hline Adj. R_DISC & $-0.162 * * *$ & -3.740 & $-0.421 * * *$ & -3.720 & $\begin{array}{l}-0.102 * * \\
{[2.75]^{* * *}}\end{array}$ & -2.180 \\
\hline SIZE & 0.026 & 1.050 & 0.091 & 1.270 & 0.019 & 0.730 \\
\hline LEV & $-0.544 * * *$ & -6.180 & $-0.620 * * *$ & -2.770 & $-0.520 * * *$ & -5.430 \\
\hline VOL & $0.267 * * *$ & 9.360 & $0.224 * * *$ & 2.780 & $0.277 * * *$ & 9.110 \\
\hline STDROA & $-1.082 * * *$ & -3.520 & $-2.562 * * *$ & -3.270 & $-0.822 * * *$ & -2.610 \\
\hline $\mathrm{B} / \mathrm{M}$ & $0.783 * * *$ & 8.800 & $0.465^{*}$ & 1.960 & $0.824 * * *$ & 8.560 \\
\hline OWNCEN & -0.008 & -0.080 & $0.561 *$ & 1.950 & -0.093 & -0.920 \\
\hline BIG4 & -0.073 & -1.290 & -0.145 & -0.920 & -0.072 & -1.190 \\
\hline DUALITY & -0.019 & -0.470 & 0.026 & 0.270 & -0.027 & -0.620 \\
\hline BSIZE & $-0.013 *$ & -1.650 & -0.038 & -1.540 & -0.011 & -1.360 \\
\hline DIND & -0.260 & -0.970 & -1.230 & -1.590 & -0.194 & -0.680 \\
\hline Constant & $-7.413 * * *$ & -16.480 & $-7.263 * * *$ & -5.390 & $-7.525 * * *$ & -15.720 \\
\hline Industry dummies & & & & & & \\
\hline Year dummies & & & & & & \\
\hline $\mathrm{N}$ & & & & & & \\
\hline $\operatorname{Adj} . \mathrm{R}^{2}$ & & & & & & \\
\hline
\end{tabular}

This table presents the regression of the effects of industry-adjusted risk disclosure on stock price synchronicity for the full sample (Panel A) and the subsamples (Panel B). A firm is classified as internationally oriented if foreign sales account for $25 \%$ of total sales (e.g., O'Conner et al., 2009; Knight and Cavusgil, 2004). The dependent variable used in this table is $\boldsymbol{S Y N C H}(\mathbf{1})$, computed as $\log \left[\mathrm{R}^{2} /\left(1-\mathrm{R}^{2}\right)\right]$, where $\mathrm{R}^{2}$ is estimated based on Eq. (1) using the daily returns of the 30 trading days following the risk disclosure release dates. The other variables are defined as follows: Adj. $\boldsymbol{R}_{-} \boldsymbol{D I S C}$ is measured as the firm's total score for risk disclosure minus the industry median. SIZE is the logarithm of total assets. $\boldsymbol{L E} \boldsymbol{V}$ is measured as total liabilities divided by total assets. $\boldsymbol{V O \boldsymbol { L }}$ is defined as the total number of shares traded in a year, divided by the total number of shares outstanding at the end of the fiscal year. STDROA is the standard deviation of a firm's ROA over the preceding five years, including the current year. $\boldsymbol{B} / \boldsymbol{M}$ is measured as total net assets divided by the total market value of equity at the end of the fiscal year. OWNCEN is measured as the Herfindahl index of the top 10 shareholders. BIG4 is a dummy variable that equals one if the firm is audited by one of the Big 4 audit firms. DUALITY is a dummy variable that equals one if the CEO also serves as board chair, and zero otherwise. BSIZE is measured as the logarithm of the number of board members. DIND is the percentage of independent directors. All continuous variables are winsorized at the $1^{\text {st }}$ and $99^{\text {th }}$ percentiles. The dummy variables are not. The number reported in square brackets is the t-statistic of the difference in the coefficients on Adj. R_DISC between the two subsamples. *, **, and $* * *$ denote significance at the $10 \%, 5 \%$, and $1 \%$ levels (two-sided), respectively. 
Table 8: The effect of risk disclosure on future stock price crash risk

\begin{tabular}{|c|c|c|c|c|c|c|}
\hline & \multicolumn{3}{|c|}{ NCSKEW } & \multicolumn{3}{|c|}{$D U V O L$} \\
\hline & (1) & (2) & (3) & (4) & (5) & (6) \\
\hline & Full sample & International & Domestic & Full sample & International & Domestic \\
\hline \multirow[t]{3}{*}{ R_DISC } & -0.051 & $-0.242 * * *$ & -0.014 & $-0.050 *$ & $-0.198 * * *$ & -0.019 \\
\hline & $(-1.512)$ & $(-2.851)$ & $(-0.393)$ & $(-1.887)$ & $(-3.001)$ & $(-0.661)$ \\
\hline & \multicolumn{4}{|c|}{$[-2.46]^{* *}$} & \multicolumn{2}{|c|}{$[-2.52]^{* *}$} \\
\hline \multirow[t]{2}{*}{ DTURN } & $-0.072 *$ & -0.017 & $-0.079 *$ & -0.045 & -0.000 & -0.050 \\
\hline & $(-1.805)$ & $(-0.179)$ & $(-1.765)$ & $(-1.390)$ & $(-0.002)$ & $(-1.391)$ \\
\hline \multirow[t]{2}{*}{ WRET } & $2.736 * * *$ & $4.165^{* *}$ & $2.395 * * *$ & $1.693 * * *$ & $3.809 * *$ & $1.401 * *$ \\
\hline & $(3.687)$ & $(2.436)$ & $(2.922)$ & $(2.836)$ & $(2.344)$ & (2.118) \\
\hline \multirow[t]{2}{*}{$\mathrm{M} / \mathrm{B}$} & $0.092 * * *$ & $0.130 * * *$ & $0.088 * * *$ & $0.064 * * *$ & $0.087 * * *$ & $0.062 * * *$ \\
\hline & $(7.137)$ & $(3.669)$ & $(6.402)$ & $(6.184)$ & (3.199) & $(5.584)$ \\
\hline \multirow[t]{2}{*}{ SIZE } & $0.089 * * *$ & $0.115^{* * *}$ & $0.082 * * *$ & $0.072 * * *$ & $0.092 * * *$ & $0.067 * * *$ \\
\hline & $(6.734)$ & $(3.417)$ & $(5.904)$ & $(6.600)$ & $(3.325)$ & $(5.757)$ \\
\hline \multirow[t]{2}{*}{ SIGMA } & $19.864 * * *$ & $27.828 * * *$ & $17.879 * * *$ & $13.594 * * *$ & $21.582 * * *$ & $11.890 * * *$ \\
\hline & $(4.689)$ & $(2.686)$ & $(3.863)$ & $(4.026)$ & $(2.752)$ & $(3.214)$ \\
\hline \multirow[t]{2}{*}{ LEV } & -0.058 & -0.248 & -0.004 & $-0.103 *$ & -0.197 & -0.072 \\
\hline & $(-0.791)$ & $(-1.488)$ & $(-0.051)$ & $(-1.810)$ & $(-1.453)$ & $(-1.143)$ \\
\hline \multirow[t]{2}{*}{ ROA } & $0.383^{*}$ & 0.319 & 0.357 & -0.130 & -0.061 & -0.180 \\
\hline & $(1.777)$ & $(0.607)$ & (1.499) & $(-0.752)$ & $(-0.139)$ & $(-0.947)$ \\
\hline \multirow[t]{2}{*}{ Constant } & $-3.009 * * *$ & $-3.510 * * *$ & $-2.886 * * *$ & $-2.181 * * *$ & $-2.606 * * *$ & $-2.074 * * *$ \\
\hline & $(-9.184)$ & $(-4.343)$ & $(-8.235)$ & $(-8.050)$ & $(-4.164)$ & $(-7.059)$ \\
\hline Industry dummies & YES & YES & YES & YES & YES & YES \\
\hline Year dummies & YES & YES & YES & YES & YES & YES \\
\hline $\mathrm{N}$ & 5,297 & 822 & 4,475 & 5,297 & 822 & 4,475 \\
\hline $\operatorname{Adj} . R^{2}$ & 0.103 & 0.143 & 0.099 & 0.127 & 0.178 & 0.120 \\
\hline
\end{tabular}

This table presents the regression of the effects of risk disclosure on stock price crash risk. A firm is classified as internationally oriented if foreign sales account for $25 \%$ of total sales (e.g., O'Conner et al., 2009; Knight and Cavusgil, 2004). The dependent variables used in this table are the negative conditional skewness of firm-specific weekly returns $(\boldsymbol{N C S K E W )}$ and down-to-up volatility $(\boldsymbol{D} \boldsymbol{U} \boldsymbol{V O L})$. The other variables are defined as follows: $\boldsymbol{R} \_\boldsymbol{D I S C}$ is measured as the total score for risk disclosure. SIZE is the logarithm of total assets. $\boldsymbol{L E V}$ is measured as total liabilities divided by total assets. $\boldsymbol{R} \boldsymbol{O A}$ is return on assets. $\boldsymbol{M} / \boldsymbol{B}$ is measured as the total market value of equity divided by total net assets at the end of the fiscal year. WRET is the average firm-specific weekly returns in fiscal year t - 1. DTURN is stock turnover. SIGMA is stock return volatility. All continuous variables are winsorized at the $1^{\text {st }}$ and $99^{\text {th }}$ percentiles. The dummy variables are not. The number reported in square brackets is the t-statistic of the difference in the coefficients on $R \_D I S C$ between the two subsamples. *, **, and *** denote significance at the $10 \%, 5 \%$, and $1 \%$ levels (two-sided), respectively. 
Table 9: The effect of risk disclosure on stock price synchronicity using change models

\begin{tabular}{|c|c|c|c|c|c|c|}
\hline & \multicolumn{2}{|c|}{ Panel A: Full sample analysis } & \multicolumn{4}{|c|}{ Panel B: Subsample analysis } \\
\hline & \multirow[b]{2}{*}{ Coef. } & \multirow[b]{2}{*}{ t-stat } & \multicolumn{2}{|c|}{ International } & \multicolumn{2}{|c|}{ Domestic } \\
\hline & & & Coef. & t-stat & Coef. & t-stat \\
\hline$\Delta R \_D I S C$ & -0.056 & -0.940 & $-0.313 * *$ & -2.170 & $\begin{array}{c}0.000 \\
{[2.57]^{* * *}}\end{array}$ & 0.000 \\
\hline$\Delta \mathrm{SIZE}$ & $0.204 * *$ & 2.240 & $0.684 * * *$ & 2.620 & 0.128 & 1.330 \\
\hline$\triangle \mathrm{LEV}$ & $-0.453 *$ & -1.830 & $-1.622 * *$ & -2.300 & -0.246 & -0.940 \\
\hline$\Delta \mathrm{VOL}$ & $0.444 * * *$ & 10.400 & $0.444 * * *$ & 4.000 & $0.452 * * *$ & 9.710 \\
\hline$\triangle \mathrm{STDROA}$ & -0.154 & -0.210 & $-5.525 * * *$ & -3.320 & 0.665 & 0.840 \\
\hline$\Delta \mathrm{B} / \mathrm{M}$ & 0.198 & 1.240 & 0.083 & 0.190 & 0.189 & 1.100 \\
\hline$\triangle \mathrm{OWNCEN}$ & 0.552 & 1.040 & -0.428 & -0.280 & 0.793 & 1.420 \\
\hline BIG4 & 0.055 & 0.700 & -0.331 & -1.500 & 0.096 & 1.150 \\
\hline DUALITY & 0.052 & 0.890 & 0.006 & 0.040 & 0.056 & 0.880 \\
\hline$\triangle \mathrm{BSIZE}$ & 0.003 & 0.100 & -0.131 & -1.570 & 0.016 & 0.540 \\
\hline$\triangle \mathrm{DIND}$ & 0.038 & 0.060 & $-4.895 * * *$ & -2.720 & 0.651 & 0.950 \\
\hline Constant & $0.443 * * *$ & 4.580 & $0.543 * *$ & 2.310 & $0.444 * * *$ & 4.170 \\
\hline Industry dummies & & & & & & \\
\hline Year dummies & & & & & & \\
\hline $\mathrm{N}$ & & & & & & \\
\hline $\operatorname{Adj} . R^{2}$ & & & & & & \\
\hline
\end{tabular}

This table presents the regression of the effect of risk disclosure on stock price synchronicity using change models for the full sample (Panel A) and the subsamples (Panel B). A firm is classified as internationally oriented if foreign sales account for $25 \%$ of total sales (e.g., O'Conner et al., 2009; Knight and Cavusgil, 2004). The dependent variable used in

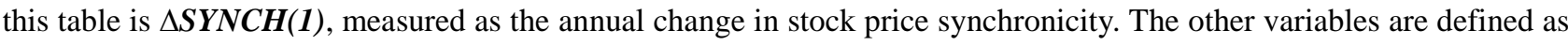
follows: $\Delta \boldsymbol{R} \_\boldsymbol{D I S C}$ is measured as the annual change in the total score for risk disclosure. $\triangle \boldsymbol{S I Z E}$ is the annual change in firm size, measured as the logarithm of total assets. $\Delta \boldsymbol{L} \boldsymbol{E} \boldsymbol{V}$ is the annual change in leverage, measured as total liabilities divided by total assets. $\triangle \boldsymbol{V O L}$ is the annual change in trading volume turnover, defined as the total number of shares traded in a year, divided by the total number of shares outstanding at the end of the fiscal year. $\triangle \boldsymbol{S T D R O A}$ is the annual change in earnings volatility, measured as the standard deviation of a firm's ROA over the preceding five years, including the current year. $\Delta \boldsymbol{B} / \boldsymbol{M}$ is the annual change in the book-to-market ratio, measured as total net assets divided

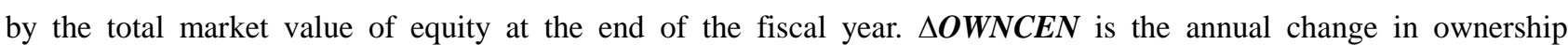
concentration, measured as the Herfindahl index of the top 10 shareholders. BIG4 is a dummy variable that equals one if the firm is audited by one of the Big 4 audit firms. DUALITY is a dummy variable that equals one if the CEO also serves as board chair, and zero otherwise. $\triangle \boldsymbol{B S I Z E}$ is the annual change in board size, measured as the logarithm of the number of board members. $\triangle \boldsymbol{D I N D}$ is the annual change in the percentage of independent directors. All continuous variables are winsorized at the $1^{\text {st }}$ and $99^{\text {th }}$ percentiles. The dummy variables are not. The number reported in square brackets is the t-statistic of the difference in the coefficients on $\Delta R \_D I S C$ between the two subsamples. *, **, and *** denote significance at the $10 \%, 5 \%$, and $1 \%$ levels (two-sided), respectively. 
Table 10: The effect of risk disclosure on stock price synchronicity using the 2SLS approach

\begin{tabular}{|c|c|c|c|c|c|c|c|c|c|c|c|c|}
\hline & \multicolumn{6}{|c|}{ Dependent=SYNCH(1) } & \multicolumn{6}{|c|}{ Dependent=SYNCH(2) } \\
\hline & \multicolumn{2}{|c|}{ Full sample } & \multicolumn{2}{|c|}{ International } & \multicolumn{2}{|c|}{ Domestic } & \multicolumn{2}{|c|}{ Full sample } & \multicolumn{2}{|c|}{ International } & \multicolumn{2}{|c|}{ Domestic } \\
\hline & Coef. & t-stat & Coef. & t-stat & Coef. & t-stat & Coef. & $\mathrm{t}$-stat & Coef. & t-stat & Coef. & t-stat \\
\hline R_DISC & $-0.159 * * *$ & -3.660 & $-0.430 * * *$ & -3.860 & $\begin{array}{l}-0.098 * * \\
{[2.88]^{* * *} *}\end{array}$ & -2.070 & $-0.099 * * *$ & -2.810 & $-0.203^{* *}$ & -2.350 & $\begin{array}{c}-0.070 * \\
{[1.70]^{*}}\end{array}$ & -1.820 \\
\hline SIZE & 0.026 & 1.050 & 0.091 & 1.290 & 0.019 & 0.720 & $0.109 * * *$ & 5.360 & $0.122 * *$ & 2.370 & $0.108 * * *$ & 4.850 \\
\hline LEV & $-0.538 * * *$ & -6.110 & $-0.623 * * *$ & -2.830 & $-0.512 * * *$ & -5.340 & $-0.499 * * *$ & -6.990 & $-0.562 * * *$ & -3.270 & $-0.488 * * *$ & -6.270 \\
\hline VOL & $0.266^{* * *}$ & 9.300 & $0.226 * * *$ & 2.850 & $0.275^{* * *}$ & 9.040 & $0.148 * * *$ & 6.370 & 0.091 & 1.560 & $0.158 * * *$ & 6.240 \\
\hline STDROA & $-1.084 * * *$ & -3.540 & $-2.541 * * *$ & -3.290 & $-0.829 * * *$ & -2.640 & $-1.172 * * *$ & -4.450 & $-1.644 * * *$ & -2.590 & $-1.058 * * *$ & -3.740 \\
\hline $\mathrm{B} / \mathrm{M}$ & $0.780 * * *$ & 8.760 & $0.482 * *$ & 2.040 & $0.818^{* * *}$ & 8.510 & $0.392 * * *$ & 5.370 & 0.166 & 0.920 & $0.422 * * *$ & 5.290 \\
\hline OWNCEN & 0.009 & 0.090 & $0.567 * *$ & 2.000 & -0.075 & -0.740 & -0.008 & -0.100 & $0.487 * *$ & 2.060 & -0.087 & -1.020 \\
\hline BIG4 & -0.074 & -1.310 & -0.147 & -0.940 & -0.074 & -1.210 & -0.027 & -0.550 & 0.163 & 1.230 & -0.061 & -1.160 \\
\hline DUALITY & -0.017 & -0.440 & 0.019 & 0.210 & -0.025 & -0.560 & -0.010 & -0.310 & 0.017 & 0.230 & -0.013 & -0.360 \\
\hline BSIZE & -0.013 & -1.630 & -0.038 & -1.580 & -0.011 & -1.340 & 0.000 & -0.010 & -0.018 & -0.890 & 0.002 & 0.230 \\
\hline DIND & -0.249 & -0.930 & -1.219 & -1.600 & -0.183 & -0.640 & $-0.399 *$ & -1.720 & $-1.134 *$ & -1.890 & -0.340 & -1.350 \\
\hline Constant & $-7.310 * * *$ & -16.190 & $-7.085 * * *$ & -5.290 & $-7.442 * * *$ & -15.500 & $-5.707 * * *$ & -15.570 & $-4.296 * * *$ & -4.350 & $-5.949 * * *$ & -15.020 \\
\hline Industry dummies & \multicolumn{2}{|c|}{ YES } & \multicolumn{2}{|c|}{ YES } & \multicolumn{2}{|c|}{ YES } & \multicolumn{2}{|c|}{ YES } & \multicolumn{2}{|c|}{ YES } & \multicolumn{2}{|c|}{ YES } \\
\hline Year dummies & \multicolumn{2}{|c|}{ YES } & \multicolumn{2}{|c|}{ YES } & \multicolumn{2}{|c|}{ YES } & \multicolumn{2}{|c|}{ YES } & \multicolumn{2}{|c|}{ YES } & \multicolumn{2}{|c|}{ YES } \\
\hline $\mathrm{N}$ & \multicolumn{2}{|c|}{5,410} & \multicolumn{2}{|c|}{845} & \multicolumn{2}{|c|}{4,565} & \multicolumn{2}{|c|}{5,410} & \multicolumn{2}{|c|}{845} & \multicolumn{2}{|c|}{4,565} \\
\hline Centered $\mathrm{R}^{2}$ & \multicolumn{2}{|c|}{0.252} & \multicolumn{2}{|c|}{0.274} & \multicolumn{2}{|c|}{0.254} & \multicolumn{2}{|c|}{0.284} & \multicolumn{2}{|c|}{0.297} & \multicolumn{2}{|c|}{0.287} \\
\hline $\begin{array}{l}\text { Sargan-Hansen test } \\
\text { (p-value) }\end{array}$ & \multicolumn{2}{|c|}{$(2.527)$} & $(4.5$ & & $(0.8$ & & $(1$. & & (1. & & $(3.1$ & \\
\hline
\end{tabular}

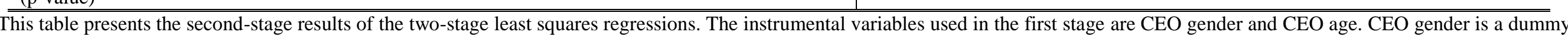

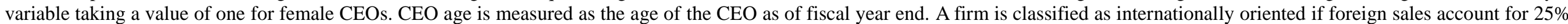

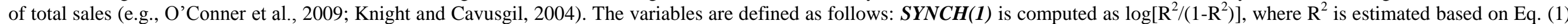

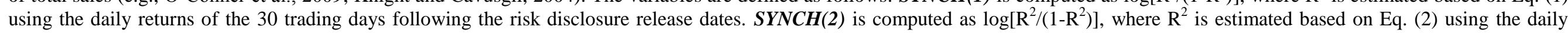

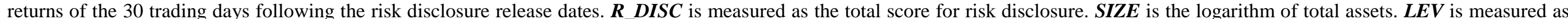

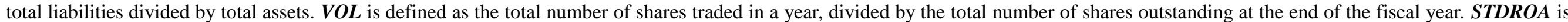

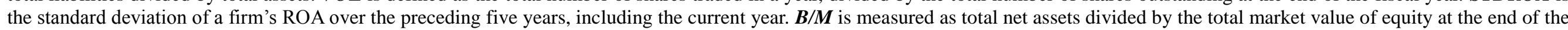

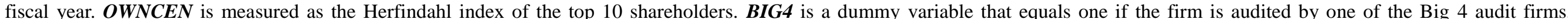

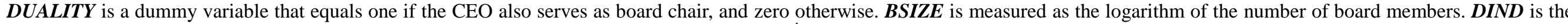

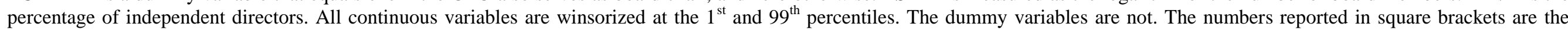

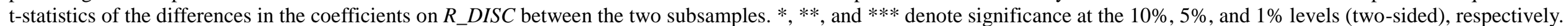


Table 11: Do internationally oriented firms disclose more risk information?

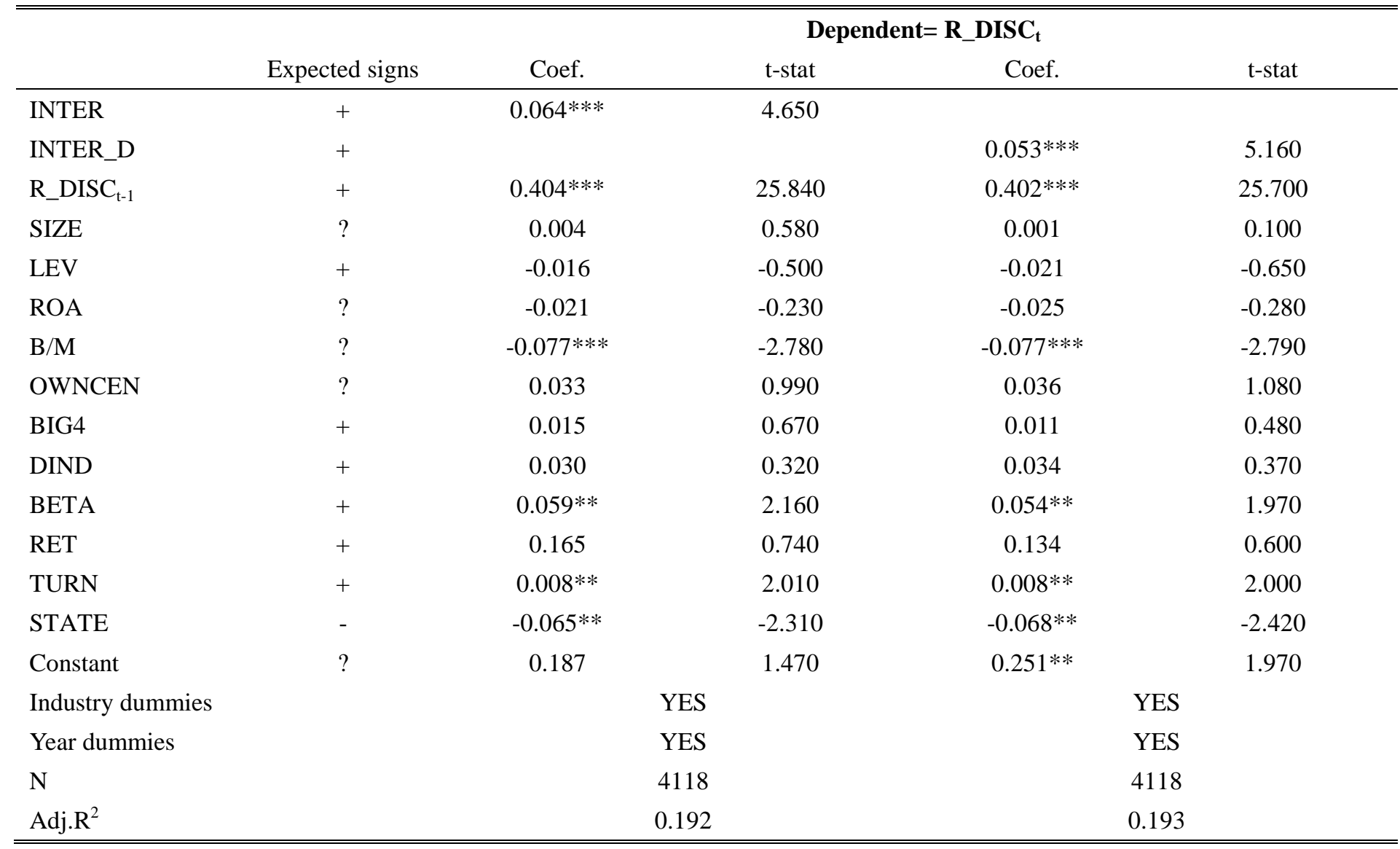

This table presents the regression investigating whether internationally oriented firms disclosed more risk information. The variables are defined as follows: $\boldsymbol{R} \_\boldsymbol{D I S C}$ is measured as the total score for risk disclosure. INTER is a dummy variable that equals one if foreign sales account for $25 \%$ of total sales, and zero otherwise. INTER_D is an alternative measure of international orientation, which equals one if there is the firm has any foreign sales and zero otherwise. SIZE is the logarithm of total assets. $\boldsymbol{L E V}$ is measured as total liabilities divided by total assets. $R \boldsymbol{O A}$ is measured as net income divided by total assets. $\boldsymbol{B} / \boldsymbol{M}$ is measured as total net assets divided by the total market value

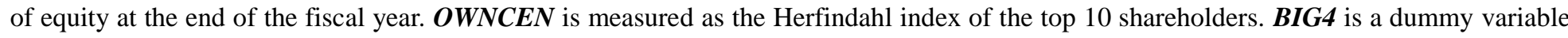
that equals one if the firm is audited by one of the Big 4 audit firms. DIND is the percentage of independent directors. BETA is a measure for firm risk obtained from the CSMAR database. $\boldsymbol{R E T}$ is the annual stock return beginning in the $5^{\text {th }}$ month of the fiscal year and ending in the $4^{\text {th }}$ month after fiscal year end. TURN is the average daily share turnover ratio during the fiscal year. STATE is the number of shares held by the government. All continuous variables are winsorized at the 1 st and 99 th percentiles. The dummy variables are not. *, **, and *** denote significance at the $10 \%, 5 \%$, and $1 \%$ levels (two-sided), respectively. 
Appendix 1: Scoring method for risk disclosure

Disclosure content

\section{Operational risks}

Potential difficulties in achieving the company's strategic objectives?

1 if yes, 0 if no

Measures for dealing with difficulties in achieving the company's strategic objectives?

Potential difficulties in achieving the company's business objectives?

Measures for dealing with difficulties in achieving the company's business objectives?

Unfavorable factors caused by industry competition?

Measures to counter the unfavorable factors caused by industry competition?

Competitive disadvantages or weaknesses?

Measures to counter competitive disadvantages or weaknesses?

\section{Investment risks}

Difficulties encountered in the company's current investment projects?

1 if yes, 0 if no

Measures for dealing with difficulties encountered in the company's current investment projects?

Difficulties related to the company's planned new investment projects?

Measures for dealing with difficulties related to the company's planned new investment projects?

\section{Financial risks}

Difficulties associated with financing (e.g., interest rate, exchange rate, liquidity, credit, 1 if yes, 0 if no mergers \& acquisitions and so forth)

Measures for dealing with financial risks?

1 if yes, 0 if no

\section{New product/R\&D risks}

Difficulties related to the company's planned new products or services?

1 if yes, 0 if no

Measures for dealing with difficulties related to the company's planned new products or

1 if yes, 0 if no services?

Potential difficulties associated with the company’s R\&D projects?

1 if yes, 0 if no

Measures for dealing with the potential difficulties associated with the company's $R \& D \quad 1$ if yes, 0 if no projects? 
Appendix 2: Variable definitions

\begin{tabular}{ll}
\hline Variable & $\begin{array}{l}\text { Definition } \\
R^{2}\end{array}$ \\
& $\begin{array}{l}\mathrm{R}^{2} \text { of either of the market models calculated using the } \\
\text { following the risk disclosure release dates. }\end{array}$ \\
$\operatorname{SYNCH}(1)$ & $\mathrm{Ln}\left[\mathrm{R}^{2} /\left(1-\mathrm{R}^{2}\right)\right]$, where $\mathrm{R}^{2}$ is estimated based on Eq. (1). \\
$\operatorname{SYNCH}(2)$ & $\mathrm{Ln}\left[\mathrm{R}^{2} /\left(1-\mathrm{R}^{2}\right)\right]$, where $\mathrm{R}^{2}$ is estimated based on Eq. (2).
\end{tabular}

NCSKEW The negative coefficient of skewness, calculated by taking the negative of the third moment of firm-specific weekly returns for each sample year and dividing it by the standard deviation of firm-specific weekly returns raised to the third power. See Eq. (6) for details.

DUVOL For each firm j over year t, we separate firm-specific weekly returns into down (up) weeks when the weekly returns are below (above) the annual mean. We separately calculate the standard deviation of firm-specific weekly returns for each of the two groups. Then, DUVOL is the natural logarithm of the ratio of the standard deviation in the down weeks to the standard deviation in the up weeks. See Eq. (7) for details.

$R \_D I S C \quad$ Total score for risk disclosure. Please see Appendix 1 for details.

NUM_RDISC Log (1+Number of sentences in the section on risk factors in the annual report).

INTER A dummy variable that equals one if foreign sales account for $25 \%$ of total sales, and zero otherwise.

INTER_D A dummy variable that equals one if foreign sales are greater than zero, and zero otherwise The logarithm of total assets at the end of the fiscal year.

LEV Leverage ratio computed as total liabilities divided by total assets.

VOL Trading volume turnover, computed as the total number of shares traded in a year divided by the total number of shares outstanding at the end of the fiscal year.

STDROA Earnings volatility, computed as the standard deviation of a firm's ROA over the preceding five years, including the current year.

$B / M$

Book-to-market ratio, defined as total net assets divided by the total market value of equity at the end of the fiscal year.

OWNCON Ownership concentration, measured as the Herfindahl index of the top 10 shareholders.

BIG4 Dummy variable that equals one if the firm is audited by one of the Big 4 auditors.

DUALITY Dummy variable that equals one if the CEO also serves as board chairman, and zero otherwise.

BSIZE

Board size, measured as the log of the number of board members.

DIND Percentage of independent directors, defined as the number of independent directors divided by the total number of board members. 
RET Annual stock return beginning in the 5th month of the fiscal year and ending in the 4th month after fiscal year end.

TURN The average daily share turnover ratio during the fiscal year.

STATE The number of shares held by the government.

DTURN The average monthly share turnover for the current fiscal year minus the average monthly share turnover for the previous fiscal year, where monthly share turnover is the monthly trading volume divided by the total number of floating shares on the market that month.

SIGMA The standard deviation of firm-specific weekly returns over the fiscal year.

$R O A$ The income before extraordinary items divided by total assets. 